\title{
A Japanese logographic character frequency list for cognitive science research
}

\author{
NOBUKO CHIKAMATSU \\ DePaul University, Chicago, Illinois \\ SHOICHI YOKOYAMA \\ National Language Research Institute of Japan, Tokyo, Japan \\ HIRONARI NOZAKI \\ Aichi University of Education, Kariya, Japan \\ ERIC LONG \\ National Language Research Institute of Japan, Tokyo, Japan \\ and \\ SACHIO FUKUDA \\ Yokohama National University, Yokohama, Japan
}

\begin{abstract}
This paper describes a Japanese logographic character (kanji) frequency list, which is based on an analysis of the largest recently available corpus of Japanese words and characters. This corpus comprised a full year of morning and evening editions of a major newspaper, containing more than 23 million kanji characters and more than 4,000 different kanji characters. This paper lists the 3,000 most frequent kanji characters, as well as an analysis of kanji usage and correlations between the present list and previous Japanese frequency lists. The authors believe that the present list will help researchers more accurately and efficiently control the selection of kanji characters in cognitive science research and interpret related psycholinguistic data.
\end{abstract}

In many empirical psycholinguistic studies, word frequency is used as an independent variable to select materials having desired frequency characteristics or as a control variable to match two or more sets of materials in order to minimize performance differences attributable to word frequency effects in word recognition, memory, or retrieval performance. It is sometimes important in psycholinguistic research to focus on the frequency effects of linguistic units smaller than words, such as letter clusters (e.g., bigrams or trigrams), syllabic-type units (syllable vs. nonsyllable), morpheme units, as well as position (i.e., word-initial, word-middle, or word-final positions; Appleman \& Mayzner, 1981; Grainger \& Jacobs, 1993; Srinivas, Roediger, \& Rajaram, 1992). For example, logographic character frequency is a crucial factor to consider in word experiments using languages with logographic scripts, such as Chinese, Japanese, or Korean, where each logographic character may function as a word (Matsunaga, 1996). In short, it is important to carefully control the frequency of printed characters and/or words when empirical psycholinguistic studies are conducted.

The authors thank the reviewers of the paper for their valuable suggestions. Correspondence concerning this article may be sent to N. Chikamatsu, Department of Modern Languages, DePaul University, 802 West Belden Avenue, Chicago, IL 60614 (e-mail: nchikama@) condor.depaul.edu)
In the past, compiling linguistic corpora was an extremely labor-intensive process, plagued by reliability concerns caused by human error. However, as computer technology continues to develop, researchers are obtaining more reliable linguistic corpora and compiling word or character frequency lists on the basis of these corpora for linguistic or cognitive science research. For American English, some widely used word frequency lists are the Brown corpus (Kučera \& Francis, 1967), the American Heritage Word Frequency Book (Carroll, Davies, \& Richman, 1971), and the Thorndike-Lorge count (Thorndike \& Lorge, 1944; see the summary in Solso, Juel, \& Rubin, 1982). Many of these corpora and lists are available in computer database form and/or through the Internet. Consequently, researchers may use these corpora and lists to control word frequency in empirical language research more easily, efficiently, and accurately than in the past. Corpora for non-English languages, including Japanese, remain limited in number or are still under development (Edwards, 1993; Leech \& Fligelstone, 1992).

\section{Word and Character \\ Frequency Lists in Japanese}

Over the last two decades, researchers in the area of experimental psychology, especially word recognition and memory, have increasingly focused on the Japanese language, owing to the uniqueness of its writing system (Kess 
\& Miyamoto, 1994; Paradis, Hagiwara, \& Hildebrandt, 1985; Yokoyama, 1997). In particular, kanji (characters in a logographic script that is one of three scripts used in writing Japanese) has been widely used in experimental materials in order to examine new aspects of cognitive processing, relative to alphabetic language systems, in word recognition and memory and hemispheric involvement in the acquisition and usage of language. However, although many studies have been conducted that use Japanese words, the development of Japanese word frequency lists or kanji character frequency lists has not kept up with the demand for such lists. As a result, for example, the kanji character or word frequency of selected kanji items has often not been controlled or mentioned in Japanese word recognition studies when frequency has not been used as a dependent variable (e.g., Eko \& Nakamizo, 1989; Flores d'Arcais \& Saito, 1993; Flores d'Arcais, Saito, Kawakami, \& Masuda, 1994; Kikuchi, 1996; Morton, Sasanuma, Patterson, \& Sakuma, 1992; Nagae, 1994; Naito \& Komatsu, 1989; Osaka, 1992; Sekiguchi \& Abe, 1992; Wang, 1988; Yokosawa \& Shimomura, 1993). In many other studies, the frequency of kanji characters or words is controlled on the basis of (1) the researcher's subjective, intuitive judgment (e.g., Flores d'Arcais, Saito, \& Kawakami, 1995; Hatta, Koike, \& Langman, 1994; Shimomura \& Yokosawa, 1991), (2) the examinee's judgment, such as subjects' rating on selected items (e.g., Yamada, Mitarai, \& Yoshida, 1991), (3) the categorization of kanji characters standardized by the Japanese Ministry of Education (e.g., Kyoiku kanji or Gakushu kanji ${ }^{1}$; see, e.g., Hayashi, 1988; Hirose, 1992; Nakagawa, 1994; Sakuma, Itoh, \& Sasanuma, 1989), (4) lists compiled by examiners themselves (e.g., Wydell, Butterworth, \& Patterson, 1995; Wydell, Patterson, \& Humphreys, 1993), or (5) the National Language Research Institute's (NLRI's) 1962 or 1976 word/character frequency lists (Cabeza, 1995; Morikawa, 1985; Naito \& Komatsu, 1988; Sasanuma, Sakuma, \& Kitano, 1992; Tsuzuki, 1993).

One of the main impediments to the development of Japanese word frequency lists is that the electronic representation of Japanese characters is more complicated than that of alphabetical languages. At present, there are three primary electronic coding systems for Japanese characters (i.e., kana and kanji): Japanese Industrial Standards (JIS), Shift-JIS (SJIS), and Extended Unix Code (EUC). Generally, EUC is used in Unix workstations on the Internet, whereas JIS is used for Japanese electronic mail. However, SJIS has been adopted for use with personal computers. Consequently, if different coding systems are used across tasks or methods, one must transfer one character code to another, using a converter such as the network kanji code conversion filter (NKF).

Another factor impeding the development of Japanese frequency lists is the Japanese writing system itself, which comprises three types of orthographies-hiragana, katakana, and kanji. Hiragana and katakana are syllabic scripts in which each symbol represents a sound unit (a syllable). These scripts each contain 46 basic forms, with additional diacritic and historical forms giving a total of 83 hiragana and 86 katakana forms encoded in JIS and EUC. Hiragana and katakana share the same syllabicsound representation and can be transcribed one by the other (e.g., a syllable / sa / is transcribed as さ in hiragana and $\forall$ in katakana). The third Japanese orthography, kanji, is a logographic script adopted from the Chinese language, in which each symbol represents meaning and functions as a morpheme. A single kanji character may represent an independent word (e.g., 本 / hon/, book) or part of a word (e.g., 本 in 日本 / nihon/, Japan). The meaning of each constituent (i.e., a single character) in a kanji word is sometimes less clear or transparent than that of an independent word. Owing to the manner in which kanji characters were transferred from the Chinese to the Japanese language over the centuries, a single kanji character may have obtained more than one reading and may be pronounced in several different ways. For instance, the character 頭, which means head, is read as / to/, /do/,/zu/, /ju/, /saki/, /atama/, / kashira/, / kobe/, /kaburi/, and / tsumuri / (Coulmas, 1989). Furthermore, a great number of homophones (i.e., kanji characters that share a common pronunciation but represent different meanings) occur in Japanese kanji usage. For instance, 木 (tree), 気 (feeling), 機 (chance), 輝 (to glow), 期 (period), and many others are all pronounced $/ \mathrm{ki} /$. Thus, in contrast to both hiragana and katakana, kanji characters do not have a systematic sound representation or a one-toone relationship between sound and symbol. The number of kanji characters is quite large and practically uncountable (i.e., kanji dictionaries may contain between 12,000 and 50,000 entries; Kindaichi, 1991; Morohashi, 1989).

Among hiragana, katakana, and kanji, usually only one is conventionally chosen and used to write a given Japanese word. Hiragana is used primarily for words that have a grammatical function, such as particles or case-makers, and for some native Japanese content words. Katakana is used for loan words (i.e., words mainly borrowed from western languages, such as English, French, and Portuguese). Kanji is used for content words, such as nouns, verbs, and adjectives. ${ }^{2}$ Thus, a single Japanese sentence is usually written with all three scripts combined.

However, choice of script is not always consistent and may vary, depending on a writer's intention or a publisher's guidelines for style. For instance, the Japanese word meaning egg, pronounced / tamago/, could be written as たまこ in hiragana in one context, but as 卵 in kanji in another context. In their study of the subjective frequency of script type, Ukita, Sugishima, Minagawa, Inoue, and Kashu (1996) studied 750 Japanese words that can be written in more than one Japanese script. The study was conducted by asking 836 Japanese college students to judge whether a given word (written in a given script) is seen often, occasionally, or rarely. The results showed that more than half of the tested words were identified as words seen in more than one script. This inconsistency in orthographic representation makes word counting in Japanese extremely difficult and complicated. In addition, word segmentation in Japanese is more complex than that in English, since word boundaries are not separated with 
spaces in written texts. A single kanji character could be a morpheme of a part of a word or a word by itself and may be pronounced differently, depending on the context. Without clear word boundaries, compound words are easily formed. Thus, complications in word counting and segmentation present nontrivial challenges for those compiling word frequency lists in Japanese.

Owing to these problems, few have attempted to make word and kanji character frequency lists in Japanese. The NLRI in Japan published a word frequency list in 1962, based on a corpus derived from 90 different journals and magazines with five different genres, all published in 1956. A total of 140 million tokens, consisting of 40,000 different words (i.e., types), were analyzed in order to develop a frequency list of words possessing a frequency of at least nine. In 1976, the NLRI also published a kanji (character) frequency list based on a corpus published in 1966 derived from three major newspapers, Asahi, Yomiuri, and Mainichi. This corpus provided a total of 991,375 kanji tokens and a frequency list of 3,213 different kanji characters. This was the first attempt to analyze a Japanese corpus with computers, and the results were used to standardize and regulate the use of kanji characters for mass media and education in Japan. For the past three decades, researchers have used these lists as an informative resource for many language-related research projects. In 1997, the NLRI published its 1962 list in floppy disk format (NLRI, 1997).

However, several problems are associated with the use of the NLRI lists for empirical studies. First, the lists are based on dated media samples. Almost three or four decades have passed since the corpora of the 1962 and 1976 lists were collected. Consequently, the reliability of these lists is open to question, since the use of words or kanji in mass media and education may have changed. Second, the 1976 list does not identify low-frequency kanji. The 1962 word list does not contain words possessing a frequency less than nine, and the 1976 kanji list does not provide characters possessing a frequency less than nine. Low-frequency words or characters with the frequency of one are required for many empirical language studies. Third, the lists are not easily accessed, since both were available only in hard copy form until recently. Although the NLRI 1962 list is now available in floppy disk format ${ }^{3}$ it is not as accessible, especially to researchers outside Japan, as other language lists that are available over the Internet. It is crucial that these lists be accessible to researchers in computer database format to help make the control and selection of word and kanji frequency simpler, more effective, and more accurate.

In 1994, the situation for Japanese corpus linguistics changed for the better, when CD-ROM databases of newspaper articles became available at a relatively low cost. These computerized corpora of newspapers made it possible to develop an updated kanji frequency list accessible on computers and over the Internet.

The purpose of the present project is to develop a new kanji character frequency list to be made accessible through the Internet. In consideration of the word segmentation and other problems mentioned above, the authors decided to start by developing frequency lists of kanji characters before attempting kanji word frequency lists. Furthermore, the current usage of kanji in printed mass media is analyzed on the basis of a comparison with 1966 frequencies from the NLRI 1976 list.

\section{Source of Data, Method of Analysis, and Results}

The present corpus is available on a CD-ROM entitled CD-HIASK'93 (Nichigai Associates \& Asahi, 1994), which contains the text of articles appearing in a major newspaper, covering 1 year of morning and evening editions published in 1993. The data analysis was conducted on Unix workstations, with the program written by the authors in Perl and awk. First, headlines were excluded ${ }^{4}$ from the approximately 110,000 articles $^{5}$ in the data. Second, all the printable characters were counted and ranked by frequency from highest to lowest in each category (e.g., kanji, hiragana, or katakana). Frequency ratio (\%) and cumulative frequency ratio $(\%)$ were also calculated.

The corpus provided a total of 56,563,595 printable characters, ${ }^{6}$ making it, at the time, the largest corpus used for the compilation of Japanese word/character frequency lists. Ideally, in addition to newspapers, corpora would be collected from other printed texts, such as magazines and novels of various genres. However, most of these printed materials are not yet available in computerreadable form. As a result, it is not currently feasible to gather sufficient amounts of data from these materials. Furthermore, copyright issues complicate the process of copying and studying printed mass media in Japan and may pose an obstacle to making lists based on such materials freely available to the public.

The $56,563,595$ characters in the 1993 collection of the Asahi newspaper form the basis of the present character frequency list and break down into the general categories shown in Table 1. A total of 23,408,236 kanji tokens were found, making up 4,476 different types. Kanji covered $41 \%$ of all the printable characters in the newspapers. The central result of this survey is a list of the kanji characters found, sorted according to their frequencies. The first 3,000 characters are listed in Appendix A with their ranking, raw frequency, frequency ratio (\%), and cumulative frequency ratio (\%). In addition, frequency lists of hiragana and katakana characters are also included in Appendices $\mathrm{B}$ and $\mathrm{C},{ }^{7}$ respectively, with the same headings.

Cumulative percentage of kanji character use. The cumulative frequency ratio of kanji characters, ranked from high to low frequency, is shown in Table 2. Although it has been conventionally said among learners and teachers of Japanese that knowledge of 2,000-3,000 kanji characters is required for one to read Japanese newspapers, this conventional wisdom was not supported by the present data. According to the results of the present analysis, the top 500 most frequent kanji characters accounted for approximately $80 \%$ of total kanji use. Furthermore, the top 1,600 most frequent characters covered $99 \%$ 
Table 1

Printable Character Type Totals

\begin{tabular}{lrrr}
\hline \multicolumn{1}{c}{ Characters } & Types & \multicolumn{1}{c}{ Tokens } & Frequency Ratio $(\%)$ \\
\hline Kanji & 4,476 & $23,408,236$ & 41.38 \\
Hiragana & 83 & $20,711,361$ & 36.62 \\
Katakana & 86 & $3,608,288$ & 6.38 \\
Punctuation and symbols & 99 & $7,406,035$ & 13.09 \\
Arabic numerals & 10 & $1,169,902$ & 2.07 \\
Latin alphabet & 52 & 259,773 & 0.46 \\
\hline
\end{tabular}

of total use and the rest- that is, the next 3,000 characters-made up only $1 \%$ of the total kanji use.

The cumulative frequency ratio obtained from the 1966 corpus (i.e., the NLRI 1976 list) is also indicated in Table 2. The results from the two corpora, which are 30 years apart, indicate almost identical ratios for each frequency level. Furthermore, according to the current frequency list, of the 500 most frequent characters ranked in 1966, 445 characters are also ranked among the 500 most frequent characters in the 1993 corpus, but all of those 55 characters lower than the first 500 fall within the 1,000 most frequent characters in the 1993 corpus. Thus, the high-frequency kanji characters that account for over $80 \%$ of the total kanji use have not changed much in the last 30 years.

Correlation coefficient of chronological character use. To examine change in kanji usage over the past 30 years, a correlation analysis was conducted between the present 1993 list and the NLRI 1976 list based on the 1966 newspaper corpus. The raw frequencies of the 3,000 highest frequency characters in the present list ${ }^{8}$ and the equivalent characters in the NLRI 1976 list were converted to their base- 10 logarithmic equivalents ${ }^{9}$ and submitted to a Pearson correlation coefficient analysis. The result indicates a high correlation $(r=.95)$ and was significant $[F(1,3029)=28,037.67, p<.01]$. In Figure 1, although low-frequency characters scatter more than highfrequency characters, the distribution is close to linear. ${ }^{10}$ Thus, on the basis of the analysis, it appears that the overall pattern of kanji usage has not significantly changed over the past 30 years.

\section{Discussion}

In the present project, the authors introduced the first computer-based kanji character frequency lists derived from the largest corpus of Japanese newspaper texts. It is important to control the frequency of kanji characters in psycholinguistic studies, although researchers have often neglected this variable, owing to the unavailability of reliable frequency lists. Using the present list, the authors have compared kanji usage observed in data from 1966 and 1993. Although changes in language usage are often discussed in Japanese linguistic studies in terms of syntax, phonology, lexicography, and pragmatics, the usage of kanji characters did not show any significant variation over the past 30 years.

However, there are several issues left to discuss in the present study. First, the corpus of the present word list was developed from a single newspaper. Although the newspaper used in the present project is a major Japanese newspaper that currently publishes 10 million copies every day for 120 million people in Japan (one paper is usually read by more than one person), there may be some bias in terms of the selection of topics and style. Goto (1995) warned of this problem for researchers using a corpus derived from newspapers, arguing that newspapers usually focus heavily on politics, economics, and foreign policy. As a result, vocabulary related to those areas may appear in newspapers more often than in other types of published materials. In addition, each newspaper has its own regulations or standards for choosing words and expressions. Furthermore, the number of newspaper writers, compared with the number of readers, is limited, and consequently, the effects of idiosyncratic writing styles and word selection may be exaggerated, causing a bias in any analysis based exclusively on such data. Since the present character list was made from a corpus of newspapers, future research should be aimed at employing a variety of genres and types of publications to develop linguistic corpora.

To examine this issue of the bias in the present newspaper corpus, a correlation analysis of kanji frequency was conducted among the present list developed with 1993 newspapers, the NLRI 1962 list with 1956 magazines, and the NLRI 1976 list with 1966 newspapers. The results indicated a significant and high correlation between the 1956 magazine list and the 1966 newspaper list $(r=.92, p<.01)$, and between the 1956 magazine list and the 1993 newspaper list, $(r=.89, p<.01$; see Table 3$)$. The higher correlation between the 1956 and 1966 lists was probably due to the closer timing of data collection, compared with that between the 1956 and 1993 lists. However, these high correlation results may indicate that the data collected from a single newspaper in this present analysis may be a reliable resource for predicting kanji character frequency in printed mass media in general.

To examine the reliability of the present list, an additional correlation analysis was conducted with the kanji characters grouped according to frequency level. The 3,000 ranked characters were divided into three groups: (1) high-frequency characters ranked from 1 through $1,000,(2)$ mid-frequency characters ranked from 1,000

Table 2

Cumulative Frequency Ratio of Kanji Character Use

\begin{tabular}{ccc}
\hline & \multicolumn{2}{c}{ Cumulative Frequency Ratio (\%) } \\
\cline { 2 - 3 } Frequency Rank & 1993 & 1966 \\
\hline 10 & 10.00 & 10.61 \\
50 & 27.41 & 27.64 \\
100 & 40.71 & 40.15 \\
200 & 57.02 & 56.05 \\
500 & 80.68 & 79.42 \\
1,000 & 94.56 & 93.88 \\
1,500 & 98.63 & 98.40 \\
2,000 & 99.72 & 99.63 \\
2,500 & 99.92 & 99.90 \\
3,000 & 99.97 & 99.98 \\
\hline
\end{tabular}

Note-Frequency rank = size of the group of highest frequency characters. 


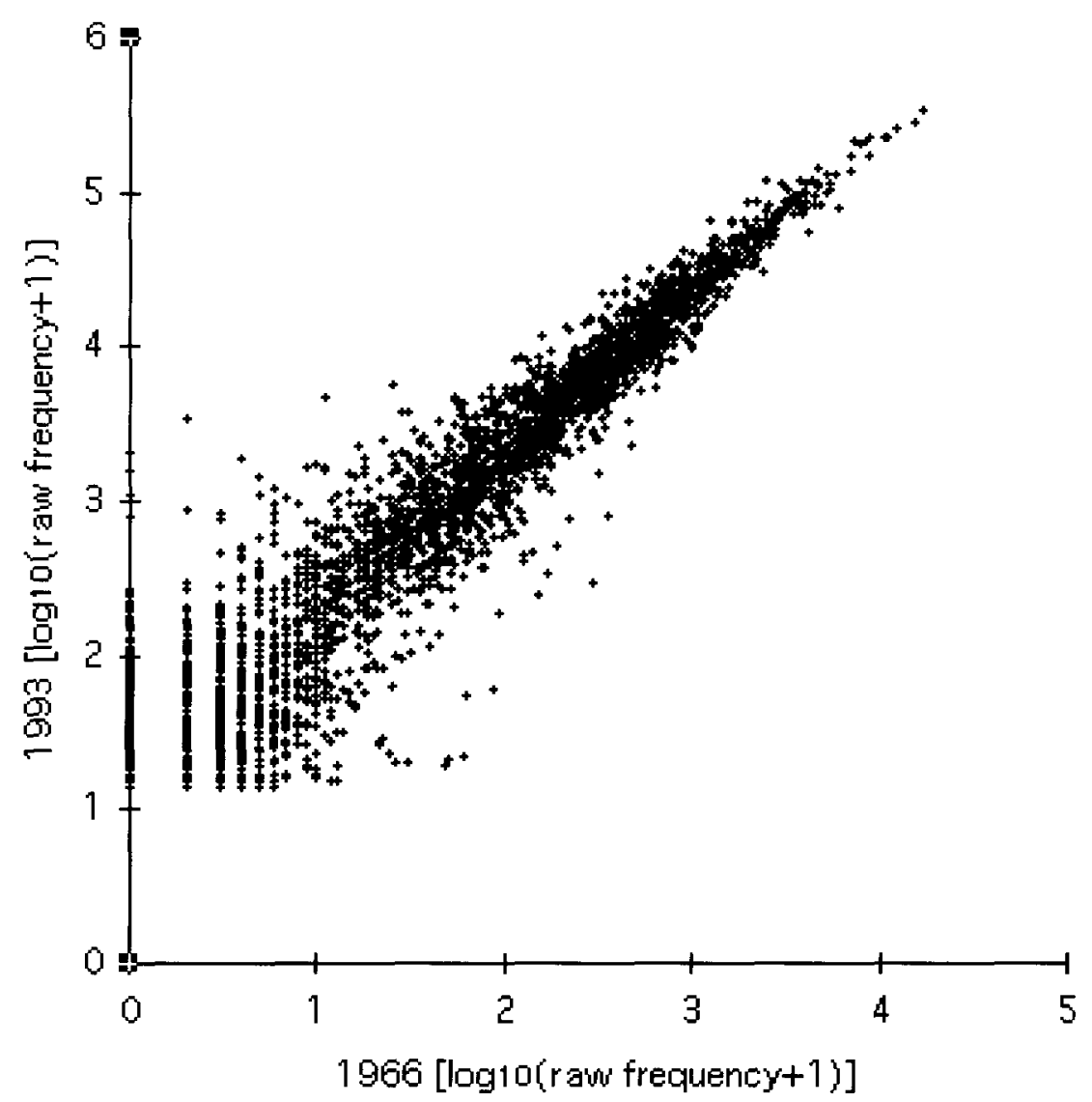

Figure 1. Kanji usage correlation distributions of top 3,000 characters between 1966 and 1993.

though 2,000, and (3) low-frequency characters ranked from 2,001 through 3,000. Although the correlations vary, depending on the levels and lists, all were significant at the $p<.01$ level (see Table 4).

The results indicate high correlations at the highfrequency levels between the present list and the other two lists. Notably, a high correlation of the 1993 newspaper list with the 1966 newspaper list at the highfrequency level $(r=.92)$ indicates again that the present list can be a reliable resource, especially at the highfrequency levels, although the data were collected from a single newspaper.

In contrast, at the low-frequency levels, the correlations of the present list are low with the 1966 list $(r=.43)$ and with the 1956 list $(r=.28)$. This may imply a drastic change of kanji usage over the decades or some unreliability of the present list at the low-frequency level. The first interpretation is easily dismissed, considering the overall high correlations with other lists, as indicated in Table 3, and the similar low correlation between the 1966 and 1956 lists at low-frequency level $(r=.40)$, which were developed relatively close in time. Does this mean that the present list is not reliable at the low-frequency list? That does not have to be the conclusion. The most likely interpretation is that the low correlations are due to the differences in size of the corpora of the three lists.
The size of the 1993 kanji corpus was much greater than the other two, containing $23,408,236$ tokens and 4,476 types. The 1966 list was compiled on the basis of 991,375 kanji tokens and 3,213 types, and the 1956 list was based on 280,094 kanji tokens and 3,328 types. Since the present correlation analysis was conducted with the 3,000 highest ranked characters in the 1993 list, some characters did not even exits in the 1966 or 1956 list. For instance, among the 38 characters ranked at 2,996 in the 1993 list, 17 characters were not included in the 1956 list, and 23 characters were not included in the 1966 list. Thus, the size difference in the corpus seems to be the most probable reason for the low correlation between the lists. If that is the case, the largest corpus could be the most reliable information for low-frequency characters-that is, the present list can be plausibly used as the most

Table 3

Correlation of Kanji Frequency Among 1993, 1966, and 1956 Lists With All 3,000 Ranked Characters

\begin{tabular}{crrr}
\hline List & $\frac{1993 \mathrm{~N}}{r}$ & $\frac{1966 \mathrm{~N}}{r}$ & $\frac{1956 \mathrm{M}}{r}$ \\
\hline $1993 \mathrm{~N}$ & 1.00 & & \\
$1966 \mathrm{~N}$ & .95 & 1.00 & \\
$1956 \mathrm{M}$ & .89 & .92 & 1.00 \\
\hline
\end{tabular}

Note- $\mathrm{N}$, newspapers; $\mathrm{M}$, magazines. 
Table 4

Correlation of Kanji Frequency Among 1993, 1966, and 1956 Lists With High-, Mid-, and Low-Frequency Ranked Characters

\begin{tabular}{cccc}
\hline & & $1966 \mathrm{~N}$ & \\
\cline { 3 - 3 } List & Frequency & $r$ & $r$ \\
\hline $1993 \mathrm{~N}$ & high & .92 & .80 \\
& mid & .68 & .55 \\
\multirow{3}{*}{$1966 \mathrm{~N}$} & low & .43 & .28 \\
& high & 1.00 & .86 \\
& mid & 1.00 & .60 \\
& low & 1.00 & .40 \\
\hline
\end{tabular}

Note- $\mathrm{N}$, newspapers; $\mathrm{M}$, magazines. High = characters ranked from 1 st through 1,000th. Mid = characters ranked from 1,001st through 2,000 th. Low $=$ characters ranked from 2,001 st through 3,000 th.

reliable resource. Thus, the correlation analysis among the three lists can support the high reliability of the present list.

Another issue relating to the present project is the reliability of a computerized Japanese corpus (i.e., $C D$ HIASK'93), transformed from the original hard copy form (i.e., the Asahi newspaper). There are few instances in which kanji characters appearing in the newspaper did not appear encoded as kanji in the current CD-ROM corpus. The original locations of those characters in the newspaper were marked by symbol characters, such as the "geta mark" (二) in the electronic format (Yokoyama, Sasahara, Nozaki, \& Long, 1998). This is due to several revisions made in JIS, ${ }^{11}$ which is an electronic character encoding standard and assigns a code to approximately 6,300 kanji characters. Although only a few hundred of these cases were observed out of 23 million kanji tokens in the current CD-ROM corpus and these were among the lowest frequent characters, this inconsistency between printed and electronic data formats should be kept in mind when low-frequency characters are used or focused on.

In the present project, a new kanji character frequency list was developed with the largest newspapers corpus in Japanese corpus linguistic history. Although there are still some issues left, the present list provides useful information on kanji usage in the current printed media. Furthermore, the present list has become available and accessible in computer database over the Internet, ${ }^{12}$ which helps researchers control and interpret logographic psycholinguistic studies more accurately and efficiently.

\section{REFERENCES}

Appleman, I. B., \& Mayzner, M. S. (1981). The letter-frequency effect and the generality of familiarity effects on perception. Perception \& Psychophysics, 30, 436-446.

CABEZA, R. (1995). Investigating the mixture and subdivision of perceptual and conceptual processing in Japanese memory tests. Memory \& Cognition, 23, 155-165.

Carroll, J. B., Davies, P., \& Richman, B. (1971). The American Heritage word frequency book. New York: American Heritage.

Coulmas, F. (1989). The writing systems of the world. Oxford: Blackwell.

EDWARDS, J. A. (1993). Survey of electronic corpora and related re- sources for language researchers. In J. A. Edwards \& M. D. Lampert (Eds.), Talking data: Transcription and coding in discourse research (pp. 263-310). Hillsdale, NJ: Erlbaum.

Eko, R., \& Nakamizo, S. (1989). Coded representations of kanji, kana and figures. Japanese Journal of Psychology, 60, 265-268.

Flores d'ARCAIS, G. B., \& SAITo, H. (1993). Lexical decomposition of complex kanji characters in Japanese readers. Psychological Research, 55, 52-63.

Flores D'Arcais, G. B., Saito, H., \& Kawakami, M. (1995). Phonological and semantic activation in reading kanji characters. Journal of Experimental Psychology: Learning, Memory, \& Cognition, 21, 34-42.

Flores d'Arcais, G. B., Saito, H., Kawakami, M., \& Masuda, H. (1994). Figural and phonological effects in radical migration with kanji characters. Advances in the Study of Chinese Language Processing, 1, 241-254.

Goto, H. (1995). Gengo kenkyu no tame no data toshite no corpus no gainen ni tsuite [Corpus for linguistic research]. Tohoku University Linguistics Journal, 4, 71-87.

GRAINGER, J., \& JACOBS, A. M. (1993). Masked partial-word priming in visual word recognition: Effects of positional letter frequency. Journal of Experimental Psychology: Human Perception \& Performance, 19, 951-964.

Hatta, T., Kolke, M., \& Langman, P. (1994). Laterality of mental imagery generation and operation: Testing with brain-damaged patients and normal adults. Journal of Clinical \& Experimental Neuropsychology, 16, 577-588.

HaYashi, R. (1988). The role of semantic attributes of the distractor word in the script type effect on Stroop color-word interference task. Japanese Journal of Psychology, 59, 1-8.

Hirose, H. (1992). An investigation of the recognition process for jukugo by use of priming paradigms. Japanese Journal of Psychology, 63, 303-309.

Kess, J., \& Mryamoto, Т. (1994). Japanese psycholinguistics: A classified and annotated research bibliography. Amsterdam: Benjamins.

KIKUCHI, T. (1996). Detection of kanji words in a rapid serial visual presentation task. Journal of Experimental Psychology: Human Perception \& Performance, 22, 332-341.

KINDAICHI, K. (1991). Shimeikai kokugo jiten [New Japanese word dictionary]. Tokyo: Sanseido.

KUČERA, H., \& FRANCIS, W. N. (1967). Computational analysis of presentday American English. Providence RI: Brown University Press.

LeECH, G., \& Fligelstone, S. (1992). Computers and corpus analysis. In C. S. Butler (Ed.), Computers and written texts (pp. 115-140). Oxford: Blackwell.

Matsunaga, S. (1996). The linguistic nature of kanji reexamined: Do kanji represent only meaning? Journal of the Association of Teaching of Japanese, 30, 1-22.

MORIKAWA, Y. (1985). Stroop phenomena in the Japanese language: II. Effects of character-usage frequency and number of strokes. In H. S. R. Kao \& R. Hoosain (Eds.), Linguistics, psychology \& Chinese language (pp. 73-80). Hong Kong: University of Hong Kong Centre of Asian Studies.

MorohaSHI, T. (1989). Dai kanwa jiten [Japanese kanji character dictionary]. Tokyo: Taishuu-kan.

Morton, J., Sasanuma, S., Patterson, K., \& Sakuma, N. (1992). The organization of the lexicon in Japanese: Single and compound kanji. British Journal of Psychology, 83, 517-531.

NAGAE, S. (1994). Semantic processing functions of kanji and kana words in the right hemisphere. Japanese Journal of Psychology, 65, 144-149.

Naito, M., \& Komatsu, S. (1988). Attributes of memory that mediate priming effects in perceptual identification. Japanese Journal of $P$ sychology, 58, 352-358.

Naito, M., \& Komatsu, S. (1989). Effects of conceptually driven processing on perceptual identification. Japanese Psychological Research, 31, 45-56.

NaKAGAWA, A. (1994). Visual and semantic processing in reading kanji. Journal of Experimental Psychology: Human Perception \& Performance, 20, 864-875. 
National Language Research Institute of Japan (1962). Gendai zasshi 90 shi no yogo yoji [The total vocabulary and their written forms in ninety magazines of today]. Tokyo: Shuuei-sha.

National Language Research Institute of Japan (1976). A study of the use of Chinese characters in modern newspapers (The National Language Research Institute Report 56). Tokyo: Shuuei Shuppan.

National Language Research InStitute of Japan (1997). Gendai zasshi 90shi no yogo yoji: FD format [The total vocabulary and their written forms in ninety magazines of today]. Tokyo: Sanseido.

Nichigai Associates, \& AsaHI [Newspaper] (1994). CD-HIASK'93. Tokyo: Kinokuniya

Nozaki, H., Chikamatsu, N., \& Yokoyama, S. (1997). Compiling katakana frequency lists from Japanese newspaper corpus. Unpublished manuscript. Aichi University of Education, Nagoya.

OsaKA, M. (1992). Effect of memory set-size upon event related potentials for concrete and abstract kanji stimuli. Perceptual \& Motor Skills, 75, 401-402.

Paradis, M., Hagiwara, H., \& Hildebrandt, N. (1985). Neurolinguistic aspects of the Japanese writing system. New York: Academic Press.

Sakuma, N., ITOH, M., \& Sasanuma, S. (1989). Recognition units of kanji words: Priming effects on kanji recognition. Japanese Journal of Psychology, 60, 1-8.

Sasanuma, S., Sakuma, N., \& Kitano, K. (1992). Reading kanji without semantics: Evidence from a longitudinal study of dementia. Cognitive Neuropsychology, 9, 465-486.

Sekiguchi, H., \& ABE, I. (1992). Functional hemisphere differences in recognition of words expressed in kanji. Japanese Journal of Educational Psychology, 40, 315-322.

Shimomura, M., \& Yokosawa, K. (1991). Processing of kanji and kana characters within Japanese words. Perception \& Psychophysics, 50, 19-27.

Solso, R. L., Juel, C., \& Rubin, D. C. (1982). The frequency and versatility of initial and terminal letters in English words. Journal of Verbal Learning \& Verbal Behavior, 21, 220-235.

SRinivas, K., Roediger, H. L., III, \& Rajaram, S. (1992). The role of syllabic and orthographic properties of letter cues in solving word fragments. Memory \& Cognition, 20, 219-230.

ThORNDIKE, E. L., \& LoRGE, I. (1944). The teacher's word book of 30,000 words. New York: Columbia University, Teachers College Press.

Tsuzukı, T. (1993). Effects of context-dependent and context-independent associative strength between prime and target words on the processing of lexical ambiguity. Japanese Journal of Psychology, 64, 191-198.

Ukita, J., Sugishima, I., Minagawa, N., Inoue, M., \& Kashu, K. (1996). Nihongo no hyoki keitai ni kansuru shinrigaku kenkyuu [Research on written forms of Japanese words] (Japanese Psychological Monographs 25). Tokyo: Japanese Psychological Association.

WANG, J. (1988). Do phonological and semantic processing of kanji finish at the same time? Japanese Journal of Psychology, 59, 252-255.

Wydell, T. N., ButTerworth, B., \& PATterson, K. (1995). The inconsistency of consistency effects in reading: The case of Japanese kanji. Journal of Experimental Psychology: Learning, Memory, \& Cognition, 21, 1155-1168.

Wydell, T. N., Patterson, K. E., \& Humphreys, G. W. (1993). Phonologically mediated access to meaning for kanji: Is a rows still a rose in Japanese kanji? Journal of Experimental Psychology: Learning, Memory, \& Cognition, 19, 491-514.

Yamada, J., Mitaral, Y., \& Yoshida, T. (1991). Kanji words are easier to identify than katakana words. Psychological Research, 53, 136141 .
Yokosawa, K., \& Shimomura, M. (1993). On the role of stimulus similarity and segmentation in misprint detection. In D. Brogan, A. Gale, \& K. Carr (Eds.), Visual search 2 (pp. 371-378). London: Taylor \& Francis.

YoKoYAMA, S. (1997). Hyoki to kioku [Orthography and free recall] (Japanese Psychological Monographs 26). Tokyo: Japanese Psychological Association.

Yokoyama, S., Sasahara, H., Nozaki, H., \& Long, E. (1998). Shinbun denshi media no kanji [A study of kanji in electronic newspaper media]. Tokyo: Sanseido.

\section{NOTES}

1. The set of Kyoiku kanji contains 881 characters to be taught in elementary schools. These characters were selected by the Ministry of Education in 1948. This set was revised, and 1,006 characters were selected and defined as Gakushu kanji for the same purpose in 1989.

2. Verbs, adjectives, and adverbs are often written in a combination of kanji and kana characters. The stem of those words, which does not change in conjugation, is written in kanji, and the inflectional endings in hiragana. For instance, 食べ/ta-beru/(to eat), 大きい/oo-kii/ (big), and 早</ haya-ku/ (early) are all written with the first character in kanji and the rest in hiragana.

3. Owing to Japanese copyright ownership issues, it may not be feasible to provide the 1976 NLRI kanji list in computer database form in the near future

4. Headlines were excluded from the present analysis because inconsistencies were observed in headlines in hard copy versions of the newspapers, as compared with headlines downloaded from the CD-ROM.

5. In addition to the articles downloaded from CD-ROM, 114 articles were input manually into the database, since they were not included in the CD-ROM.

6. These printable characters include kanji, hiragana, katakana, Latin alphabets, Arabic numerals, punctuation, and symbols (commas, periods, quotation markers, etc.).

7. Appendix C, katakana frequency list, is cited from Nozaki, Chikamatsu, and Yokoyama (1997).

8. The first 3,000 ranks included 3,031 characters in the 1993 list.

9. Logarithmic transformation was used because the data were positively skewed - that is, there were more low-frequency characters and fewer high-frequency characters. A value of 1 was added before the logarithmic transformation, - that is, $\log 10$ (raw frequency+1) instead of $\log 10$ (raw frequency). This is because many of lowest frequency characters in the 1993 list were not found at all in the 1966 list (i.e., zero occurrence), which would make the logarithmic transformation impossible.

10. No value of logarithmic transformation was plotted between 0 and 1 in the $y$-axis because all top 3,000 ranked characters occurred more than 13 times in the 1993 list and the value of $\log 10$ (raw frequency +1 ) was more than 1 .

11. JIS has been revised four times over the last two decades, in 1978, 1983, 1990, and 1997. In each revision, a few new codes were added or replaced with old codes for kanji characters. Consequently, although it is very rare, some characters may appear different, depending on the version used for decoding on computers. For instance, four kanji characters that are part of the 1983 JIS standard were replaced by symbol characters on the CD-ROM. For further discussion, see Yokoyama et al. (1998).

12. The presently developed kanji character frequency list is available at http://nozaki-lab.ics.aichi-edu.ac.jp/ on the World-Wide Web. 
APPENDIX A

Kanji Character Frequency List

\begin{tabular}{|c|c|c|c|c|c|c|c|c|c|c|c|c|c|c|c|c|c|}
\hline \multirow{3}{*}{$\frac{\mathrm{R}}{1}$} & \multirow{3}{*}{$\begin{array}{l}\mathrm{C} \\
\text { 日 }\end{array}$} & \multirow[b]{2}{*}{$\Gamma$} & \multirow{2}{*}{\multicolumn{3}{|c|}{$R$}} & & & & \\
\hline & & & & & & $\mathrm{R}$ & C & $\mathrm{F}$ & $R$ & $\mathrm{c}$ & $F$ & $\mathrm{R}$ & $\mathrm{C}$ & $F$ & $\mathrm{R}$ & $\mathrm{C}$ & $F$ \\
\hline & & 336465 & 51 & 発 & 79543 & 101 & 取 & 50477 & 151 & 持 & 36776 & 201 & 向 & 29488 & 251 & 切 & 25212 \\
\hline 2 & - & 285089 & 52 & 方 & 79040 & 102 & 用 & 50447 & 152 & 支 & 36750 & 202 & 絬 & 29372 & 252 & 福 & 24992 \\
\hline 3 & + & 254534 & 53 & 高 & 76965 & 103 & 治 & 50357 & 153 & 和 & 36728 & 203 & 岡 & 29329 & 253 & 変 & 24944 \\
\hline 4 & $=$ & 223075 & 54 & 内 & 76927 & 104 & 現 & 49844 & 154 & 加 & 35822 & 204 & 込 & 29150 & 254 & 店 & 24852 \\
\hline 5 & 人 & 218967 & 55 & 白 & 76402 & 105 & 法 & 49730 & 155 & 海 & 35672 & 205 & 共 & 29075 & 255 & 案 & 24761 \\
\hline 6 & 大 & 218693 & 56 & 金 & 75885 & 106 & 気 & 49272 & 156 & 続 & 35583 & 206 & 品 & 28933 & 256 & 屋 & 24643 \\
\hline 7 & 年 & 216931 & 57 & 七 & 75735 & 107 & 経 & 49270 & 157 & 此 & 35472 & 207 & 信 & 28881 & 257 & 得 & 24601 \\
\hline 8 & 会 & 214989 & 58 & 定 & 72917 & 108 & 公 & 48710 & 158 & 安 & 35185 & 208 & 局 & 28645 & 258 & 住 & 24598 \\
\hline 9 & 国 & 199502 & 59 & 子 & 72711 & 109 & 話 & 48152 & 159 & 進 & 34984 & 209 & 集 & 28644 & 259 & 木 & 24517 \\
\hline 10 & $\equiv$ & 173495 & 60 & 的 & 72485 & 110 & 最 & 47347 & 160 & 売 & 34845 & 210 & 活 & 28343 & 260 & 台 & 24395 \\
\hline 11 & 本 & 170127 & 61 & 対 & 72438 & 111 & 野 & 47088 & 161 & 書 & 34842 & 211 & 建 & 28332 & 261 & 始 & 24379 \\
\hline 12 & 長 & 141025 & 62 & 手 & 71638 & 112 & 川 & 46819 & 162 & 水 & 34761 & 212 & 引 & 28252 & 262 & 価 & 24237 \\
\hline 13 & 中 & 138362 & 63 & 立 & 71475 & 113 & 家 & 46750 & 163 & 知 & 34483 & 213 & 交 & 28078 & 263 & 無 & 24203 \\
\hline 14 & 五 & 129146 & 64 & 田 & 70301 & 114 & 務 & 46373 & 164 & I & 34475 & 214 & 反 & 28047 & 264 & 打 & 24143 \\
\hline 15 & 出 & 128173 & 65 & 回 & 69078 & 115 & 制 & 46263 & 165 & 近 & 34449 & 215 & 告 & 28035 & 265 & 昨 & 24010 \\
\hline 16 & 事 & 117146 & 66 & 選 & 66881 & 116 & 外 & 46208 & 166 & 指 & 34355 & 216 & 利 & 28026 & 266 & 在 & 23961 \\
\hline 17 & 社 & 116636 & 67 & 今 & 66659 & 117 & 区 & 45537 & 167 & 電 & 34184 & 217 & 億 & 27919 & 267 & 感 & 23799 \\
\hline 18 & 市 & 116094 & 68 & 連 & 65066 & 118 & 作 & 45442 & 168 & 心 & 34036 & 218 & 済 & 27543 & 268 & 費 & 23693 \\
\hline 19 & 者 & 114768 & 69 & 県 & 64462 & 119 & 性 & 45322 & 169 & 改 & 34030 & 219 & 次 & 27526 & 269 & 口 & 23422 \\
\hline 20 & 月 & 114266 & 70 & 代 & 64343 & 120 & 期 & 45294 & 170 & 物 & 33863 & 220 & 件 & 27462 & 270 & 聞 & 23384 \\
\hline 21 & 四 & 113331 & 71 & 開 & 64144 & 121 & 設 & 44641 & 171 & 点 & 33828 & 221 & 村 & 27355 & 271 & 情 & 23300 \\
\hline 22 & 九 & 113226 & 72 & 粕 & 62107 & 122 & 戦 & 44302 & 172 & 北 & 33755 & 222 & 考 & 27353 & 272 & 歳 & 23215 \\
\hline 23 & 同 & 107910 & 73 & 力 & 61533 & 123 & 名 & 44160 & 173 & 元 & 33499 & 223 & 投 & 27286 & 273 & 料 & 23190 \\
\hline 24 & 自 & 107594 & 74 & 関 & 60381 & 124 & 来 & 43502 & 174 & 文 & 334 & 224 & 減 & 27200 & 274 & 滕 & 23153 \\
\hline 25 & 政 & 104317 & 75 & 体 & 58480 & 125 & 要 & 43500 & 175 & 午 & 332 & 225 & 面 & 27115 & 275 & 諭 & 23025 \\
\hline 26 & 時 & 103394 & 76 & 明 & 58291 & 126 & 意 & $433^{\circ}$ & 176 & 記 & 330 & 225 & 派 & 27115 & 276 & 役 & 22841 \\
\hline 27 & 業 & 103093 & 77 & 山 & 58290 & 127 & 機 & 43047 & 177 & 初 & 32808 & 227 & 任 & 27108 & 277 & 示 & 22768 \\
\hline 28 & 分 & 99180 & 78 & 動 & 57575 & 128 & 言 & 423 & 178 & 報 & 32752 & 228 & 解 & 27081 & 278 & 各 & 22672 \\
\hline 29 & 上 & 98454 & 79 & 万 & 57238 & 129 & 産 & 421 & 179 & 車 & 32680 & 229 & 運 & 26996 & 279 & 営 & 22402 \\
\hline 30 & 前 & 96880 & 80 & 通 & 57128 & 130 & 成 & & 180 & 府 & 32674 & 230 & 際 & 26698 & 280 & 空 & 22371 \\
\hline 31 & 生 & 95740 & 81 & 目 & 56649 & 131 & 氏 & & 181 & 䁈 & 326 & 231 & 側 & 26673 & 281 & 参 & 22244 \\
\hline 32 & 合 & 954 & 82 & 千 & 56562 & 132 & 数 & 413 & 182 & 首 & 32609 & 232 & 広 & 26386 & 282 & 革 & 22213 \\
\hline 33 & 行 & 953 & 83 & 全 & 56089 & 133 & 権 & & 183 & 忊 & 324 & 233 & 税 & 26328 & 283 & 州 & 22108 \\
\hline 34 & 部 & 950 & 84 & 京 & 55727 & 134 & 教 & 395 & 184 & 世 & 32407 & 234 & 省 & 26272 & 284 & 基 & 22071 \\
\hline 35 & 地 & 942 & 85 & 実 & 55624 & 135 & 題 & 394 & 185 & 女 & 322 & 235 & 使 & 25994 & 285 & 流 & 22038 \\
\hline 36 & 後 & 880 & 86 & 問 & 54953 & 136 & 道 & 394 & 186 & 挙 & 319 & 236 & 增 & 25973 & 286 & 領 & 21999 \\
\hline 37 & 議 & & 87 & 決 & 54695 & 137 & 保 & 389 & 187 & 院 & 31607 & 237 & 認 & 25858 & 287 & 死 & 21864 \\
\hline 38 & 党 & & 88 & 相 & 54614 & 138 & 受 & 387 & 188 & 委 & 315 & 238 & 付 & 25779 & 288 & 井 & 21843 \\
\hline 39 & 八 & & 89 & 米 & 5456 & 139 & 勝 & 3864 & 189 & 查 & 315 & 238 & 官 & 25779 & 289 & 容 & 21808 \\
\hline 40 & 民 & & 90 & 当 & 5407 & 140 & 総 & 3863 & 190 & 界 & & 240 & 求 & 25754 & 290 & 疑 & 21612 \\
\hline 41 & 六 & & 91 & 度 & & 141 & 原 & 3840 & 191 & 団 & & 241 & 半 & 25640 & 291 & 椮 & 21533 \\
\hline 42 & 見 & & 92 & 下 & & 142 & 思 & & 192 & 校 & & 242 & 別 & 25521 & 292 & 古 & 21530 \\
\hline 43 & 問 & & 93 & 主 & & 143 & 以 & & 193 & 予 & & 243 & 阪 & 25465 & 293 & 私 & 21472 \\
\hline 44 & 新 & & 94 & 理 & 5274 & 144 & 強 & & 193 & 第 & & 244 & 企 & 25377 & 294 & 特 & 21456 \\
\hline 45 & 員 & & 95 & 表 & 52129 & 145 & 平 & 37547 & 195 & 画 & & 245 & 朝 & 25330 & 295 & 係 & 21338 \\
\hline 46 & 入 & 82282 & 96 & 化 & 52076 & 146 & 協 & 37433 & 196 & 計 & & 246 & 策 & 25292 & 296 & 格 & 21211 \\
\hline 47 & 場 & 81652 & 97 & 調 & 51942 & 147 & 組 & & 197 & 判 & & 247 & 直 & 25281 & 297 & 勢 & 20973 \\
\hline 48 & 円 & 80909 & 98 & 所 & 51314 & 148 & 島 & 37052 & 198 & 先 & & 248 & 男 & 25279 & 298 & 宮 & 20969 \\
\hline 49 & 学 & 80845 & 99 & 小 & 51107 & 149 & 都 & 36971 & 199 & 西 & 30405 & 249 & 統 & 25273 & 299 & 神 & 20783 \\
\hline 50 & 東 & 79738 & 100 & 不 & 50768 & 150 & 多 & 36947 & 200 & 重 & 30219 & 250 & 僟 & 25253 & 300 & 式 & 20690 \\
\hline$C F$ & & 274104 & $C F$ & & 40.7119 & $\mathrm{CF}$ & & 49.9366 & $\mathrm{CF}$ & & 57.0228 & $\mathrm{CF}$ & & 62.8109 & $\mathrm{CF}$ & & 67.7131 \\
\hline
\end{tabular}


APPENDIX A (Continued)

\begin{tabular}{|c|c|c|c|c|c|c|c|c|c|c|c|c|c|c|c|c|c|}
\hline & & & & & & & & & & & & & & & & & \\
\hline $\mathrm{R}$ & $C$ & $\bar{F}$ & $\mathrm{R}$ & $\mathrm{C}$ & $\mathrm{F}$ & $\mathrm{R}$ & $C$ & $\mathrm{~F}$ & $\mathrm{~K}$ & $\mathrm{C}$ & $F$ & $\mathrm{R}$ & $\mathrm{C}$ & $\mathrm{F}$ & $\mathrm{R}$ & $\mathrm{C}$ & $F$ \\
\hline 301 & 止 & 20667 & 351 & 敗 & 17216 & 401 & 庁 & 14694 & 451 & 愛 & $\overline{12884}$ & 501 & 様 & 11241 & 551 & 火 & 9865 \\
\hline 302 & 置 & 20579 & 352 & 術 & 17108 & 402 & 武 & 14668 & 452 & 横 & 12865 & 502 & 園 & 11203 & 552 & 他 & 9828 \\
\hline 303 & 果 & 20557 & 353 & 説 & 17106 & 403 & 造 & 14659 & 453 & 旅 & 12820 & 503 & 橋 & 11197 & 553 & 満 & 9827 \\
\hline 304 & 放 & 20507 & 354 & 足 & 17040 & 404 & 佐 & 14601 & 454 & 被 & 12773 & 504 & 答 & 11174 & 554 & 録 & 9805 \\
\hline 305 & 割 & 20281 & 355 & 施 & 16982 & 405 & 与 & 14566 & 455 & 供 & 12765 & 505 & 隊 & 11130 & 555 & 丸 & 9796 \\
\hline 306 & 裁 & 20234 & 356 & 食 & 16925 & 406 & 視 & 14564 & 456 & 造 & 12713 & 506 & 察 & 11115 & 556 & 夜 & 9792 \\
\hline 307 & 少 & 20100 & 357 & 補 & 16851 & 407 & 副 & 14471 & 457 & 室 & 12706 & 507 & 移 & 11066 & 557 & 悉 & 9780 \\
\hline 308 & 土 & 20027 & 358 & 起 & 16798 & 408 & 試 & 14383 & 458 & 映 & 12685 & 508 & 児 & 11047 & 558 & 融 & 9768 \\
\hline 309 & 演 & 19987 & 359 & 乗 & 16746 & 409 & 質 & 14369 & 459 & 末 & 12631 & 509 & 程 & 11046 & 559 & 分 & 9762 \\
\hline 310 & 有 & 19917 & 360 & 球 & 16712 & 410 & 限 & 14335 & 460 & 負 & 12610 & 510 & 細 & 11037 & 560 & 候 & 9722 \\
\hline 311 & 線 & 19884 & 361 & 断 & 16709 & 411 & 路 & 14264 & 461 & 個 & 12585 & 511 & 独 & 11020 & 561 & 河 & 9711 \\
\hline 312 & 石 & 19633 & 362 & 残 & 16660 & 412 & 態 & 14262 & 462 & 器 & 12552 & 512 & 光 & 11012 & 562 & 討 & 9708 \\
\hline 313 & 語 & 19561 & 363 & 額 & 16657 & 413 & 景 & 14202 & 463 & 低 & 12544 & 513 & 捕 & 10955 & 563 & 単 & 9699 \\
\hline 314 & 過 & 19517 & 364 & 導 & 16610 & 414 & 象 & 14129 & 464 & 若 & 12482 & 514 & 命 & 10871 & 564 & 達 & 9684 \\
\hline 315 & 終 & 19363 & 365 & 算 & 16602 & 415 & 技 & 14120 & 465 & 字 & 12461 & 515 & 推 & 10822 & 565 & 林 & 9642 \\
\hline 316 & 必 & 19359 & 366 & 南 & 16563 & 416 & 助 & 14113 & 466 & 道 & 12443 & 516 & 洋 & 10796 & 566 & 奻 & 9634 \\
\hline 317 & 転 & 19320 & 367 & 港 & 16520 & 417 & 郎 & 14053 & 466 & 差 & 12443 & 517 & 徫 & 10795 & 567 & 署 & 9624 \\
\hline 318 & 確 & 19254 & 368 & 証 & 16463 & 418 & 準 & 13949 & 468 & 値 & 12393 & 518 & 専 & 10790 & 568 & 極 & 9595 \\
\hline 319 & 両 & 19246 & 369 & 真 & 16324 & 419 & 待 & 13933 & 469 & 種 & 12334 & 519 & 失 & 10752 & 569 & 系 & 9546 \\
\hline 320 & 送 & 19104 & 370 & 究 & 16308 & 420 & 験 & 13911 & 470 & 鉄 & 12259 & 520 & 評 & 10695 & 570 & 非 & 9532 \\
\hline 321 & 状 & 18976 & 371 & 沢 & 16280 & 421 & 境 & 13818 & 471 & 風 & 12175 & 521 & 帰 & 10644 & 571 & 針 & 9444 \\
\hline 322 & 害 & 18815 & 372 & 病 & 16259 & 422 & 親 & 13817 & 472 & 申 & 12148 & 522 & 白 & 10564 & 572 & 識 & 9436 \\
\hline 323 & 提 & 18796 & 373 & 談 & 16201 & 423 & 席 & 13803 & 473 & 味 & 12137 & 523 & 兵 & 10563 & 573 & 久 & 9377 \\
\hline 324 & 位 & 18746 & 374 & 争 & 16165 & 424 & 形 & 13788 & 474 & 整 & 12125 & 524 & 訪 & 10557 & 574 & 憲 & 9337 \\
\hline 325 & 研 & 18714 & 375 & 急 & 16136 & 425 & 展 & 13711 & 475 & 盲 & 11987 & 525 & 辺 & 10535 & 575 & 吉 & 9317 \\
\hline 326 & 護 & 18702 & 376 & 楽 & 16093 & 426 & 頭 & 13708 & 476 & 退 & 11983 & 525 & 請 & 10535 & 576 & 庫 & 9314 \\
\hline 327 & 収 & 18605 & 377 & 松 & 16063 & 427 & 戸 & 13646 & 477 & 守 & 11968 & 527 & 呼 & 10451 & 577 & 森 & 9311 \\
\hline 328 & 再 & 18596 & 378 & 落 & 16052 & 428 & 谷 & 13624 & 478 & 注 & 11946 & 528 & 離 & 10447 & 578 & 並 & 9310 \\
\hline 329 & 消 & 18557 & 379 & 援 & 16023 & 429 & 働 & 13525 & 479 & 返 & 11923 & 529 & 深 & 10345 & 579 & 益 & 9281 \\
\hline 330 & 軍 & 18521 & 380 & 製 & 16017 & 430 & 涗 & 13490 & 480 & 罣 & 11863 & 530 & 師 & 10289 & 580 & 接 & 9254 \\
\hline 331 & 能 & 18513 & 381 & 何 & 16005 & 431 & 仕 & 13480 & 481 & 型 & 11808 & 531 & 史 & 10288 & 581 & 登 & 9160 \\
\hline 332 & 比 & 18385 & 382 & 率 & 15978 & 432 & 菓 & 13479 & 482 & 太 & 11804 & 532 & 処 & 10249 & 582 & 薪 & 9104 \\
\hline 333 & 銀 & 18379 & 383 & 宅 & 15916 & 433 & 早 & 13458 & 483 & 天 & 11756 & 533 & 段 & 10228 & 583 & 撃 & 9101 \\
\hline 334 & 商 & 18302 & 384 & 例 & 15729 & 434 & 抹 & 13379 & 483 & 客 & 11756 & 534 & 材 & 10224 & 584 & 券 & 9083 \\
\hline 335 & 輸 & 18194 & 385 & 備 & 1570 & 435 & 監 & 1331 & 485 & 影 & 11739 & 535 & 販 & 10220 & 585 & 搜 & 9081 \\
\hline 336 & 崎 & 18109 & 386 & 可 & 15703 & 436 & 授 & 13292 & 486 & 財 & 11721 & 536 & 積 & 10197 & 586 & 故 & 9009 \\
\hline 337 & 撆 & 18075 & 387 & 培 & 15625 & 437 & 量 & 13285 & 487 & 含 & 11681 & 537 & 㱑 & 10107 & 587 & 閣 & 9000 \\
\hline 338 & 規 & 18056 & 388 & 構 & 15566 & 437 & P凧 & 13285 & 488 & 望 & 11648 & 538 & 振 & 10094 & 588 & 城 & 8998 \\
\hline 339 & 由 & 17958 & 389 & 番 & 15514 & 439 & 票 & 13241 & 489 & 紙 & 11624 & 539 & 修 & 10093 & 589 & 秋 & 8989 \\
\hline 340 & 農 & 17877 & 390 & 張 & 15401 & 440 & 想 & 1321 & 490 & 観 & 115 & 540 & 競 & 10057 & 590 & 青 & 8975 \\
\hline 341 & 常 & 17855 & 391 & 声 & 15245 & 441 & 然 & 1319 & 491 & 買 & 11465 & 541 & 婦 & 10029 & 591 & Q & 8951 \\
\hline 342 & 応 & 17850 & 392 & 美 & 1524 & 442 & 渡 & 1315 & 492 & 努 & 11440 & 542 & 号 & 10023 & 592 & 周 & 8940 \\
\hline 343 & 育 & 17845 & 393 & 着 & 15190 & 443 & 審 & 1312 & 493 & 科 & 11433 & 543 & 雄 & 9992 & 593 & 韓 & 8902 \\
\hline 344 & 違 & 17785 & 394 & 担 & 15101 & 444 & 課 & 13069 & 494 & 䋨 & 11398 & 544 & 階 & 9991 & 594 & 編 & 8892 \\
\hline 345 & 夫 & 17655 & 395 & 労 & 15078 & 445 & 良 & 13056 & 495 & 花 & 11388 & 545 & 根 & 9986 & 595 & 責 & 8867 \\
\hline 346 & \pm & 17596 & 396 & 佂 & 14952 & 446 & 伝 & 13043 & 496 & 復 & 11306 & 546 & 船 & 9967 & 596 & 寄 & 8856 \\
\hline 346 & 義 & 17596 & 397 & 域 & 14941 & 447 & 英 & 13009 & 497 & 春 & 11296 & 547 & 賞 & 9944 & 597 & 模 & 8847 \\
\hline 348 & 身 & 17527 & 398 & 難 & 14846 & 448 & 管 & 13004 & 498 & 述 & 11293 & 548 & 赤 & 9908 & 598 & 鲜 & 8815 \\
\hline 349 & 配 & 17505 & 399 & 防 & 14835 & 449 & 条 & 13000 & 499 & 好 & 11289 & 549 & 歌 & 9882 & 599 & 図 & 8737 \\
\hline 350 & 館 & 17362 & 400 & 幹 & 14780 & 450 & 念 & 12958 & 500 & 去 & 11273 & 550 & 浜 & 9873 & 600 & 催 & 8733 \\
\hline CF & & 71.7398 & CF & & 75.1727 & $\mathrm{CF}$ & & 78.1088 & $\mathrm{CF}$ & & 80.6841 & $\mathrm{CF}$ & & 82.9314 & $\overline{\mathrm{CF}}$ & & 4.9251 \\
\hline
\end{tabular}


APPENDIX A (Continued)

\begin{tabular}{|c|c|c|c|c|c|c|c|c|c|c|c|c|c|c|c|c|c|}
\hline $\mathrm{R}$ & $\mathrm{C}$ & $\mathrm{F}$ & $\mathrm{R}$ & $\mathrm{C}$ & $\mathrm{F}$ & $\mathrm{R}$ & C & F & $\mathbf{R}$ & $\mathrm{C}:$ & $F$ & $\mathrm{R}$ & $\mathrm{C}$ & $F$ & $\mathrm{R}$ & $\mathrm{C}$ & $\mathrm{F}$ \\
\hline 601 & 右 & $\overline{8727}$ & 651 & 核 & 7701 & 701 & 占 & 6760 & 751 & 厚 & 6064 & 801 & 徳 & 5313 & 851 & 逶 & 4810 \\
\hline 602 & 央 & 8705 & 652 & 療 & 7693 & 702 & 留 & 6748 & 752 & 辞 & 6063 & 801 & 固 & 5313 & 852 & 老 & 4798 \\
\hline 603 & 走 & 8703 & 653 & 余 & 7692 & 703 & 罪 & 6740 & 753 & 香 & 6062 & 803 & 震 & 5300 & 853 & 雉 & 4796 \\
\hline 604 & 江 & 8700 & 654 & 週 & 7691 & 704 & 級 & 6736 & 754 & 湾 & 6021 & 803 & 熊 & 5300 & 854 & 狙 & 4787 \\
\hline 605 & 障 & 8656 & 655 & 波 & 7654 & 705 & 竹 & 6735 & 755 & 暴 & 6009 & 805 & 坂 & 5293 & 855 & 削 & 4780 \\
\hline 605 & 易 & 8656 & 656 & 完 & 7624 & 706 & 短 & 6728 & 756 & 压 & 6003 & 806 & 㴚 & 5292 & 856 & 臨 & 4760 \\
\hline 607 & 清 & 8652 & 657 & 織 & 7616 & 707 & 等 & 6725 & 757 & 勤 & 5980 & 807 & 測 & 5280 & 857 & 搷 & 4759 \\
\hline 608 & 速 & 8614 & 658 & 類 & 7594 & 708 & 換 & 6689 & 758 & 抗 & 5949 & 808 & 賛 & 5273 & 858 & 咸 & 4754 \\
\hline 609 & 博 & 8547 & 659 & t: & 7545 & 709 & 将 & 6683 & 759 & 倍 & 5939 & 809 & 倒 & 5270 & 859 & 為 & 4747 \\
\hline 610 & 欧 & 8543 & 660 & 䒜 & 7507 & 710 & 尾 & 6664 & 760 & 背 & 5920 & 809 & 旬 & 5270 & 860 & 昇 & 4724 \\
\hline 611 & 友 & 8533 & 661 & 津 & 7503 & 711 & 芸 & 6632 & 761 & 昭 & 5845 & $8 I I$ & 普 & 5254 & 861 & 羕 & 4720 \\
\hline 612 & 秒 & 8517 & 662 & 顔 & 7492 & 712 & 毎 & 6627 & 762 & 途 & 5831 & 812 & 版 & 5251 & 862 & 儀 & 4716 \\
\hline 613 & 督 & 8505 & 663 & 駅 & 7454 & 713 & 締 & 6625 & 763 & 居 & 5817 & 813 & 停 & 5231 & 863 & 努 & 4715 \\
\hline 614 & 健 & 8477 & 664 & 就 & 7440 & 714 & 寺 & 6623 & 764 & 貨 & 5811 & 814 & 築 & 5217 & 864 & 混 & 4710 \\
\hline 615 & 休 & 8473 & 665 & 复 & 7423 & 715 & $\mathrm{~T}$ & 6590 & 765 & 带 & 5768 & 815 & 脱 & 5208 & 865 & 橲 & 4701 \\
\hline 616 & 除 & 8472 & 666 & 舞 & 7422 & 716 & 植 & 6556 & 766 & 順 & 5766 & 816 & 執 & 5201 & 866 & 温 & 4675 \\
\hline 617 & 渉 & 8468 & 667 & 廃 & 7402 & 717 & 羽 & 6552 & 767 & 押 & 5747 & 817 & 軽 & 5196 & 867 & 菑 & 4674 \\
\hline 618 & 飛 & 8448 & 668 & 装 & 7382 & 718 & 亡 & 6545 & 768 & 曲 & 5742 & 818 & 練 & 5172 & 868 & 縄 & 4672 \\
\hline 619 & 献 & 8444 & 669 & 降 & 7376 & 719 & 迎 & 6536 & 769 & 岸 & 5738 & 819 & 康 & 5169 & 869 & 創 & 4663 \\
\hline 619 & $H_{-1}$ & 8444 & 670 & 批 & 7357 & 720 & 績 & 6529 & 770 & 徒 & 5727 & 820 & 街 & 5163 & 870 & 絶 & 4637 \\
\hline 621 & 存 & 8443 & 671 & 否 & 7351 & 721 & 旅 & 6527 & 771 & 崩 & 5724 & 821 & 浦 & 5158 & 871 & 郵 & 4627 \\
\hline 622 & 航 & 8430 & 672 & 賀 & 7339 & 722 & 妍 & 6524 & 772 & 源 & 5703 & 822 & 避 & 5143 & 872 & 密 & 4623 \\
\hline 623 & 介 & 8422 & 673 & 破 & 7285 & 723 & 盟 & 6507 & 773 & 彼 & 5686 & 823 & 辌 & 5141 & 873 & 令 & 4622 \\
\hline 624 & 給 & 8327 & 674 & 紀 & 7224 & 723 & 喜 & 6507 & 774 & 則 & 5650 & 824 & 列 & 5120 & 874 & 恵 & 4612 \\
\hline 625 & 蔵 & 8320 & 675 & 脳 & 7201 & 725 & 沛 & 6505 & 775 & 輪 & 5647 & 825 & 損 & 5118 & 875 & 契 & 4595 \\
\hline 626 & 超 & 8298 & 676 & 價 & 7188 & 726 & 陸 & 6501 & 776 & 精 & 5635 & 825 & 患 & 5118 & 876 & 繰 & 4591 \\
\hline 627 & 座 & 8248 & 677 & 孷 & 7176 & 727 & 標 & 6488 & 777 & 逆 & 5618 & 827 & 載 & 5109 & 877 & 救 & 4585 \\
\hline 628 & 採 & 8194 & 678 & 䓱 & 7175 & 728 & 払 & 6480 & 778 & 囲 & 5601 & 828 & 爆 & 5106 & 878 & 届 & 4553 \\
\hline 629 & 殺 & 8165 & 679 & 便 & 7168 & 729 & 替 & 6472 & 779 & 聴 & 5590 & 829 & 居 & 5094 & 879 & 䶘 & 4532 \\
\hline 630 & 徉 & 8156 & 680 & 歴 & 7135 & 730 & 奈 & 6447 & 780 & 善 & 5587 & 830 & 募 & 5082 & 880 & 願 & 4521 \\
\hline 631 & 末 & 8129 & 681 & 拔 & 7106 & 731 & 皇 & 6380 & 780 & 删 & 5587 & 831 & 陣 & 5080 & 881 & 恐 & 4513 \\
\hline 632 & 色 & 8125 & 682 & 危 & 7083 & 732 & 許 & 6372 & 782 & 池 & 5584 & 832 & 像 & 5064 & 882 & 遊 & 4512 \\
\hline 633 & 險 & 8106 & 683 & 延 & 7069 & 733 & 因 & 6355 & 783 & 踏 & 5572 & 833 & 馥 & 5056 & 883 & 掲 & 4499 \\
\hline 634 & 富 & 8102 & 684 & 冷 & 7061 & 734 & 伸 & 6332 & 784 & 服 & 5568 & 834 & 漁 & 5037 & 884 & 息 & 4492 \\
\hline 635 & 幅 & 8101 & 685 & 舆 & 7036 & 735 & 熱 & 6327 & 785 & 適 & 5547 & 835 & 乱 & 5024 & 885 & 致 & 4466 \\
\hline 636 & 鹿 & 8098 & 685 & 越 & 7036 & 736 & 政 & 6324 & 786 & 犯 & 5499 & 836 & 卒 & 5021 & 886 & 納 & 4452 \\
\hline 637 & 旧 & 8090 & 687 & 霖 & 7023 & 737 & 永 & 6310 & 787 & 遅 & 5496 & 837 & 迫 & 5018 & 887 & 幕 & 4449 \\
\hline 638 & 䛃 & 8069 & 688 & 異 & 6959 & 738 & 継 & 6276 & 788 & 壘 & 5477 & 838 & 絡 & 4984 & 888 & 枚 & 4446 \\
\hline 639 & 遺 & 8047 & 689 & 父 & 6921 & 739 & 王 & 6251 & 789 & 倉 & 5458 & 839 & 遣 & 4981 & 889 & 貢 & 4439 \\
\hline 640 & 札 & 8007 & 690 & 㓺 & 6910 & 740 & 散 & 6237 & 790 & 䧇 & 5439 & 840 & 䦚 & 4967 & 890 & 血 & 4433 \\
\hline 641 & 激 & 8002 & 690 & 拡 & 6910 & 741 & 玉 & 6233 & 791 & 角 & 5433 & 841 & 星 & 4961 & 891 & 更 & 4432 \\
\hline 642 & 摘 & 7982 & 692 & 逮 & 6902 & 742 & 油 & 6225 & 792 & 僚 & 5427 & 842 & 緊 & 4930 & 892 & 輩 & 4431 \\
\hline 643 & 突 & 7968 & 693 & 貿 & 6891 & 743 & 妻 & 6224 & 793 & 路 & 5388 & 843 & 諸 & 4918 & 893 & 䖳 & 4407 \\
\hline 644 & 黒 & 7943 & 694 & 及 & 6874 & 744 & 属 & 6217 & 794 & 欠 & 5346 & 844 & 惑 & 4904 & 894 & 箱 & 4404 \\
\hline 645 & 写 & 7915 & 695 & 素 & 6836 & 745 & 禁 & 6210 & 795 & 郡 & 5344 & 845 & 彦 & 4887 & 895 & 䞗 & 4400 \\
\hline 646 & 豊 & 7908 & 695 & 覚 & 6836 & 746 & 志 & 6186 & 796 & 雨 & 5333 & 846 & 鳥 & 4874 & 896 & 染 & 4397 \\
\hline 647 & 具 & 7901 & 697 & 賴 & 6796 & 747 & 静 & 6159 & 797 & 層 & 5326 & 847 & 跡 & 4862 & 897 & 岐 & 4387 \\
\hline 648 & 司 & 7881 & 698 & 盛 & 6791 & 748 & 印 & 6099 & 797 & 踣 & 5326 & 848 & $z$ & 4848 & 898 & 抢 & 4379 \\
\hline 649 & 苦 & 7851 & 699 & 習 & 6780 & 749 & 維 & 6094 & 799 & 婚 & 5324 & 849 & 浮 & 4837 & 899 & 需 & 4378 \\
\hline 649 & 伊 & 7851 & 700 & 般 & 6779 & 750 & 幸 & 6067 & 800 & 宿 & 5314 & 850 & 庭 & 4823 & 900 & 兆 & 4370 \\
\hline $\mathrm{CF}$ & & 86.6954 & $\mathrm{CF}$ & & 88.2397 & $\mathrm{CF}$ & & 9.6189 & $\mathrm{CF}$ & & 0.8281 & $\mathrm{CF}$ & & 1.9183 & $C F$ & & 92.8971 \\
\hline
\end{tabular}




\begin{tabular}{|c|c|c|c|c|c|c|c|c|c|c|c|c|c|c|c|c|c|}
\hline & & & & & & & & & & & & & & & & & \\
\hline $\mathrm{R}$ & C & $\mathbf{F}$ & $\mathbf{R}$ & $\mathrm{C}$ & $F^{\prime}$ & $\mathrm{R}$ & $\mathrm{C}$ & $\mathrm{F}$ & $\mathrm{R}$ & $\mathrm{C}$ & $\mathrm{F}$ & $R$ & $\mathrm{C}$ & $F$ & $\mathrm{R}$ & C & $F$ \\
\hline 907 & 房 & 4368 & 951 & 君 & 3878 & 1000 & 泉 & $\overline{3387}$ & 1051 & 任 & 2893 & 1101 & 菱 & 2556 & 1151 & 彩 & 2262 \\
\hline 902 & 刊 & 4362 & 952 & 扱 & 3875 & 1002 & 依 & 3376 & 1052 & 治 & 2886 & 1102 & 魚 & 2554 & 1152 & 賣 & 2260 \\
\hline 903 & 著 & 4346 & 953 & 痛 & 3866 & 1003 & 埋 & 3372 & 1053 & 䑏 & 2884 & 1103 & 悲 & 2552 & 1153 & 舎 & 2259 \\
\hline 904 & E & 4345 & 954 & 秘 & 3858 & 1004 & 掩 & 3362 & 1054 & 衝 & 2883 & 1104 & 荒 & 2548 & 1154 & 衣 & 2244 \\
\hline 905 & 逃 & 4304 & 955 & 詰 & 3854 & 1005 & 宗 & 3358 & 1055 & 兴 & 2882 & 1105 & 吸 & 2537 & 1155 & 賄 & 2240 \\
\hline 906 & 原 & 4298 & 956 & 節 & 3853 & 1006 & 砂 & 3355 & 1056 & 豪 & 2876 & 1106 & 誤 & 2528 & 1155 & 童 & 2240 \\
\hline 907 & 貴 & 4293 & 957 & 陽 & 3840 & 1007 & 枠 & 3344 & 1057 & 排 & 2874 & 1106 & 握 & 2528 & 1155 & 块 & 2240 \\
\hline 908 & 招 & 4284 & 958 & 了 & 3835 & 1007 & 互 & 3344 & 1058 & 華 & 2857 & 1108 & 籍 & 2519 & 1158 & 訓 & 2239 \\
\hline 909 & 隆 & 4278 & 958 & 䋑 & 3835 & 1009 & 䮃 & 3329 & 1059 & 孝 & 2849 & 1109 & 己 & 2515 & 1159 & 朋 & 2237 \\
\hline 909 & 迷 & 4278 & 960 & 託 & 3831 & 1010 & 敬 & 3308 & 1060 & 萧 & 2848 & 1110 & 句 & 2513 & 1160 & 毛 & 2236 \\
\hline 911 & 污 & 4271 & 961 & 端 & 3827 & 1011 & 群 & 3290 & 1061 & 雪 & 2846 & 1111 & 袋 & 2509 & 1161 & 礼 & 2235 \\
\hline 912 & 他 & 4262 & 962 & 功 & 3820 & 1012 & 曜 & 3287 & 1062 & 唄 & 2814 & 1112 & 誡 & 2501 & 1162 & 炭 & 2232 \\
\hline 913 & 抑 & 4261 & 963 & 探 & 3818 & 1013 & 慎 & 3260 & 1063 & 雅 & 2810 & 1113 & 包 & 2496 & 1163 & 濃 & 2230 \\
\hline 914 & 草 & 4245 & 964 & 盤 & 3817 & 1014 & 紹 & 3254 & 1064 & 鋼 & 2807 & 1114 & 範 & 2495 & 1164 & 寝 & 2229 \\
\hline 915 & 板 & 4239 & 965 & 巻 & 3802 & 1015 & 奪 & 53 & 1065 & 照 & 2806 & 1115 & 採 & 2480 & 1165 & 洗 & 2201 \\
\hline 916 & 希 & 4230 & 966 & 却 & 3793 & 1016 & 購 & 3245 & 1066 & 隠 & 2796 & 1115 & 筆 & 2480 & 1166 & 整 & 2189 \\
\hline 917 & 暮 & 4198 & 967 & 訟 & 3773 & 1017 & 夢 & 3238 & 1067 & 剂 & 2790 & 1115 & 暫 & 2480 & 1167 & 也 & 2183 \\
\hline 918 & 措 & 4190 & 968 & 早 & 3749 & 1018 & 項 & 3220 & 1068 & 謝 & 2789 & 1118 & 析 & 2472 & 1168 & 慣 & 2179 \\
\hline 919 & 刻 & 4188 & 969 & 布 & 3731 & 1019 & 診 & 3217 & 1069 & 撮 & 2788 & 1119 & 網 & 2468 & 1169 & 昼 & 2162 \\
\hline 920 & 併 & 4174 & 970 & 笑 & 3728 & 1020 & 簡 & 3194 & 1070 & 浩 & 2787 & 1120 & 梅 & 2460 & 1170 & 㐘 & 2151 \\
\hline 921 & 承 & 4113 & 971 & 困 & 3714 & 1021 & 律 & 3186 & 1071 & 携 & 2782 & 1121 & 掦 & 2457 & 1171 & 臣 & 2149 \\
\hline 921 & 災 & 4113 & 972 & 縮 & 3707 & 1022 & 祭 & 3185 & 1072 & 巡 & 2770 & 1122 & 空 & 2452 & 1172 & 柄 & 2148 \\
\hline 921 & 孚 & 4113 & 973 & 夕 & 3704 & 1023 & 拒 & & 1073 & 吹 & 767 & 1123 & 枺 & 48 & 1173 & 宏 & 2143 \\
\hline 924 & 誌 & 4109 & 974 & 徵 & 3691 & 1024 & 促 & 49 & 1074 & 殿 & 2764 & 1124 & 潟 & 41 & 1174 & 滑 & 2141 \\
\hline 925 & 欲 & 4095 & 975 & 称 & 3649 & 1025 & 片 & 3131 & 1074 & 忠 & 2764 & 1125 & 侵 & & 1175 & 仁 & 139 \\
\hline 926 & 借 & 4077 & 976 & 閉 & 3645 & 1026 & 杉 & 3128 & 1074 & 啨 & 2764 & 1126 & 芝 & 37 & 1176 & 至 & 2135 \\
\hline 927 & 宇 & 4069 & 977 & 奥 & 3637 & 1027 & 躍 & 3114 & 1077 & 冬 & 2752 & 1127 & 茨 & 28 & 1177 & 忘 & 2133 \\
\hline 928 & 邦 & 4059 & 978 & 盗 & 3634 & 1028 & 充 & 3113 & 1078 & 茂 & 2751 & 1128 & 哲 & 2413 & 1178 & 微 & 2129 \\
\hline 929 & 秀 & 4053 & 979 & 急 & 3598 & 1029 & 免 & 3106 & 1079 & 揮 & 2744 & 1129 & 翌 & 2405 & 1179 & 歓 & 2117 \\
\hline 930 & 堂 & 4036 & 980 & 飲 & 3591 & 1030 & 刺 & 3079 & 1080 & 徹 & 2739 & 1130 & 柳 & 2397 & 1180 & 焦 & 2108 \\
\hline 931 & 複 & 4034 & 981 & 章 & 3586 & 1031 & 祉 & 3078 & 1081 & 捨 & 2737 & 1131 & 騒 & 2390 & 1181 & 掘 & 2089 \\
\hline 932 & 骨 & 4033 & 982 & 選 & 3572 & 1032 & 䟲 & 3077 & 1082 & 溥 & 2712 & 1132 & 暗 & 2388 & 1182 & 克 & 2081 \\
\hline 933 & 里 & 4031 & 983 & 誘 & 3564 & 1033 & 勧 & 3066 & 1083 & 獲 & 2687 & 1133 & 籴 & 2381 & 1183 & 抵 & 2079 \\
\hline 934 & 折 & 4024 & 984 & 弾 & 3556 & 1034 & 看 & 3055 & 1084 & 戒 & 2679 & 1134 & 模 & 2375 & 1184 & 泊 & 2075 \\
\hline 935 & 瀬 & 4019 & 985 & 貸 & 3553 & 1035 & 圈 & 3042 & 1085 & 腐 & 2670 & 1135 & 娘 & 2372 & 1185 & 似 & 2062 \\
\hline 936 & 描 & 4010 & 986 & 我 & 3548 & 1036 & 謞 & 3033 & 1086 & 柱 & 2667 & 1136 & 網 & 2349 & 1186 & 鉱 & 2061 \\
\hline 937 & 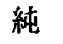 & 4009 & 987 & 控 & 3538 & 1037 & 仙 & 3032 & 1087 & 飯 & 2659 & 1137 & 塩 & 2341 & 1187 & 液 & 2057 \\
\hline 938 & 絵 & 3995 & 988 & 智 & 3531 & 1038 & 甲 & 3015 & 1088 & 敏 & 2655 & 1138 & 挑 & 233 & 1188 & 4 & 2056 \\
\hline 939 & 酒 & 3969 & 989 & 裕 & 3515 & 1039 & 埼 & 3006 & 1089 & 堀 & 2650 & 1138 & 郷 & 2335 & 1189 & 括 & 2052 \\
\hline 940 & 触 & 3963 & 990 & 預 & 3511 & 1040 & 仮 & 3004 & 1090 & 透 & 2645 & 1140 & 㖊 & 2334 & 1190 & 嶋 & 2043 \\
\hline 941 & 訳 & 3961 & 991 & 贈 & 3509 & 1041 & 壁 & 2993 & 1091 & 勉 & 2639 & 1141 & 到 & 2325 & 1191 & 鳴 & 2029 \\
\hline 942 & 鉿 & 3957 & 992 & 緒 & 3496 & 1042 & 典 & 2962 & 1092 & 駆 & 2632 & 1142 & 粶 & 2320 & 1191 & 趣 & 2029 \\
\hline 943 & 箭 & 3953 & 993 & 傾 & 3467 & 1043 & 操 & 2959 & 1093 & 隣 & 2631 & 1142 & 誕 & 2320 & 1193 & 阿 & 2028 \\
\hline 944 & 弘 & 3923 & 994 & 掛 & 3465 & 1044 & 御 & 2948 & 1094 & 掝 & 2622 & 1144 & 弟 & 2312 & 1194 & 酸 & 2025 \\
\hline 945 & 射 & 3919 & 995 & 证 & 3452 & 1045 & 恼 & 2925 & 1095 & 妥 & 2621 & 1145 & 浩 & 2303 & 1194 & 眴 & 2025 \\
\hline 946 & 弱 & 3913 & 996 & 仁 & 3451 & 1046 & 宝 & 2923 & 1096 & 數 & 2599 & 1146 & 堅 & 2294 & 1196 & 乳 & 2022 \\
\hline 947 & 択 & 3900 & 997 & 虑 & 3430 & 1046 & 銭 & 2923 & 1097 & 滞 & 2595 & 1147 & 皮 & 2281 & 1197 & 較 & 2019 \\
\hline 948 & 伴 & 3893 & 998 & 然 & 3412 & 1048 & 荷 & 2918 & 1097 & 械 & 2595 & 1148 & 裂 & 2274 & 1198 & 距 & 2011 \\
\hline 949 & 撤 & 3887 & 999 & 内 & 3393 & 1049 & 顧 & 2912 & 1099 & 眝 & 2580 & 1148 & 双 & 2274 & 1199 & 斎 & 2008 \\
\hline 950 & 奏 & 3880 & 1000 & 束 & 3387 & 1050 & 稲 & 2902 & 1100 & 茶 & 2559 & 1150 & 畑 & 2272 & 1200 & 偽 & 2002 \\
\hline$\overline{C F}$ & & $\overline{7751}$ & CF & & 94.5564 & CF & & 95.2278 & $\overline{C F}$ & & 5.8138 & $\mathrm{CF}$ & & 6.3309 & $\mathrm{CF}$ & & 5.7869 \\
\hline
\end{tabular}


APPENDIX A (Continued)

\begin{tabular}{|c|c|c|c|c|c|c|c|c|c|c|c|c|c|c|c|c|c|}
\hline \multirow{3}{*}{$\begin{array}{c}\mathrm{R} \\
1201\end{array}$} & \multirow{3}{*}{$\frac{C}{\text { 林 }}$} & \multirow[b]{2}{*}{$F$} & & & & & \\
\hline & & & $\mathrm{R}$ & C & $F$ & $\mathrm{R}$ & C & $\bar{F}$ & $\mathrm{R}$ & $\mathrm{C}$ & $\begin{array}{l}\mathrm{F} \\
\end{array}$ & $\mathrm{R}$ & $\mathrm{C}$ & $\bar{F}$ & $\mathrm{R}$ & $\mathrm{C}$ & $F$ \\
\hline & & 2000 & 1251 & 犬 & 1774 & 1301 & 虫 & 1616 & 1351 & 零 & 1425 & 1401 & 覆 & $\overline{1222}$ & 1451 & 喫 & 1075 \\
\hline 1202 & 斉 & 1996 & 1252 & 尊 & 1771 & 1301 & 喚 & 1616 & 1352 & 序 & 1424 & 1402 & 嘉 & 1221 & 1452 & 㴊 & 1070 \\
\hline 1203 & 妙 & 1991 & 1253 & 鶴 & 1767 & 1303 & 踊 & 1615 & 1353 & 孤 & 1408 & 1403 & 卓 & 1212 & 1453 & 卸 & 1067 \\
\hline 1204 & 县 & 1982 & 1254 & 縦 & 1758 & 1304 & 鯨 & 1614 & 1354 & 没 & 1406 & 1404 & 拍 & 1210 & 1454 & 尻 & 1063 \\
\hline 1205 & 浅 & 1959 & 1255 & 泳 & 1756 & 1305 & 勇 & 1612 & 1354 & 龟 & 1406 & 1405 & 㐗 & 1204 & 1455 & 磁 & 1060 \\
\hline 1205 & 飾 & 1959 & 1256 & 垣 & 1754 & 1306 & 兵 & 1611 & 1356 & 狭 & 1404 & 1405 & 曼 & 1204 & 1456 & 妹 & 1056 \\
\hline 1207 & 雲 & 1957 & 1257 & 須 & 1748 & 1307 & 陳 & 1608 & 1357 & 而 & 1395 & 1407 & 慢 & 1201 & 1456 & 帳 & 1056 \\
\hline 1208 & 领 & 1954 & 1258 & 旨 & 1747 & 1308 & 陥 & 1607 & 1357 & 恒 & 1395 & 1408 & 芳 & 1200 & 1458 & 栗 & 1054 \\
\hline 1208 & 即 & 1954 & 1259 & 幼 & 1744 & 1309 & 祖 & 1601 & 1359 & 豆 & 1391 & 1409 & 凍 & 1199 & 1458 & 艦 & 1054 \\
\hline 1210 & 湖 & 1952 & 1260 & 䁈 & 1743 & 1310 & 俳 & 1600 & 1360 & 浄 & 1389 & 1410 & 俣 & 1195 & 1460 & 浸 & 1052 \\
\hline 1211 & 硬 & 1950 & 1261 & 詩 & 1741 & 1310 & 枝 & 1600 & 1361 & 駒 & 1387 & 1410 & 彰 & 1195 & 1461 & 湿 & 1046 \\
\hline 1212 & 威 & 1946 & 1262 & 盽 & 1737 & $13 J 2$ & 牲 & 1596 & 1362 & 瞬 & 1380 & 1410 & 曙 & 1195 & 1462 & 漫 & 1045 \\
\hline 1213 & 露 & 1943 & 1263 & 冒 & 1736 & 1313 & 梶 & 1584 & 1363 & 拓 & 1377 & 1413 & 胞 & 1189 & 1463 & 冒 & 1041 \\
\hline 1214 & 閥 & 1941 & 1264 & 貞 & 1734 & 1314 & 腰 & 1578 & 1363 & 郊 & 1377 & 1413 & 彫 & 1189 & 1463 & 訂 & 1041 \\
\hline 1215 & 龩 & 1940 & 1264 & 泰 & 1734 & 1315 & 怒 & 1577 & 1365 & 彩 & 1373 & 1415 & $\pi$ & 1187 & 1463 & 刈 & 1041 \\
\hline 1216 & 矢 & 1936 & 1266 & 菜 & 1732 & 1316 & 年 & 1569 & 1366 & 糧 & 1370 & 1416 & 菌 & 1185 & 1466 & 壇 & 1040 \\
\hline 1217 & 潮 & 1933 & 1267 & 翼 & 1731 & 1317 & 龍 & 1568 & 1367 & 熟 & 1360 & 1417 & 径 & 1183 & 1467 & 淡 & 1035 \\
\hline 1218 & 鎖 & 1926 & 1268 & 畿 & 1730 & 1318 & 浪 & 1566 & 1367 & 飼 & 1360 & 1418 & 辈 & 118 & 1468 & 姉 & 1031 \\
\hline 1219 & 祝 & 1923 & 1269 & 嫌 & 1729 & 1319 & 煙 & 1562 & 1369 & 李 & 1354 & 1419 & 㷛 & 11 & 1469 & 祥 & 1030 \\
\hline 1220 & 琴 & 1922 & 1270 & 毒 & 1726 & 1320 & 跐 & 1560 & 1369 & 菊 & 135 & 1420 & 培 & 11 & 1470 & 涙 & 1028 \\
\hline 1221 & 邸 & 1919 & 1271 & 励 & 1706 & 1321 & 䜿 & 1559 & 1371 & 脚 & 1351 & 1421 & 恋 & 11 & 1471 & 尼 & 1023 \\
\hline 1221 & 积 & 1919 & 1271 & 輝 & 1706 & 1322 & 棟 & 1547 & 1372 & Int & 1346 & 1422 & 泣 & 11 & 1472 & 筒 & 1019 \\
\hline 1223 & 慶 & 1915 & 1273 & 添 & 1704 & 1323 & 丹 & 1541 & 1373 & 鏡 & 1345 & 1423 & 尋 & 11 & 1473 & 生 & 1017 \\
\hline 1224 & 是 & 1905 & 1274 & 甘 & 1688 & 1324 & 丈 & 1538 & 1374 & 立 & 1338 & 1424 & 磨 & 11 & 1474 & 忙 & 1016 \\
\hline 1225 & 旗 & 1904 & 1275 & 幌 & 1687 & 1325 & 那 & 1531 & 1375 & 粉 & 1332 & 1425 & 潜 & 11 & 1474 & 虚 & 1016 \\
\hline 1226 & 桜 & 1897 & 1276 & 沈 & 1682 & 1326 & 肥 & 1528 & 1376 & 殖 & 1329 & 1425 & 剩 & 11 & 1476 & 披 & 1014 \\
\hline 1227 & 封 & 1883 & 1277 & 蓄 & 1680 & 1327 & 溥 & 1527 & 1377 & 廷 & 1321 & 1427 & 鑑 & 11 & 1476 & 暖 & 1014 \\
\hline 1228 & 旭 & 1881 & 1277 & 奇 & 1680 & 1328 & 軸 & 1525 & 1378 & 軒 & 1320 & 1428 & 紅 & 1140 & 1476 & 征 & 1014 \\
\hline 1229 & 熙 & 1880 & 1279 & 刷 & 1677 & 1329 & 魅 & 1524 & 1379 & 基 & 130 & 1429 & 眼 & 1139 & 1479 & 唯 & 1013 \\
\hline 1230 & 浴 & 1872 & 1280 & 黄 & 1676 & 1330 & 梨 & 152 & 1380 & 寒 & 13 & 1429 & 笠 & 1139 & 1480 & 謀 & 1008 \\
\hline 1231 & 賠 & 1871 & 1281 & 梁 & 1675 & 1331 & 穂 & 151 & 1381 & 怖 & 1300 & 1431 & 陰 & 1136 & 1481 & 따 & 1000 \\
\hline 1232 & 炎 & 1870 & 1282 & 湯 & 1668 & 1332 & 緎 & 151 & 1382 & 拘 & 129 & 1432 & 阻 & 1129 & 1482 & 咲 & 997 \\
\hline 1233 & 昔 & 1867 & 1283 & 觧 & 1661 & 1333 & 帝 & 151 & 1383 & 頂 & 1297 & 1433 & 請 & 1127 & 1483 & 奇 & 995 \\
\hline 1234 & 宙 & 1864 & 1284 & 舗 & 1658 & 1334 & 穴 & 150 & 1384 & 幡 & 1292 & 1434 & 灯 & 1120 & 1484 & 妨 & 987 \\
\hline 1235 & 牧 & 1860 & 1285 & 炬 & 1656 & 1335 & 稿 & 1490 & 1385 & 喷 & 1289 & 1434 & 遂 & 1120 & 1485 & 晃 & 978 \\
\hline 35 & 兄 & 1860 & 1286 & 箱 & 1654 & 1336 & 檠 & 1489 & 1386 & 欄 & 1286 & 1436 & 謷 & 1119 & 1486 & 猶 & 973 \\
\hline 1237 & 詳 & 1 & 1287 & 竜 & 1653 & 1337 & 尽 & 1487 & 1387 & 眠 & 128 & 1436 & 尚 & 11 & 1486 & 犀 & 973 \\
\hline 1238 & 寿 & & 1288 & 岳 & 1649 & 1338 & 倫 & 1484 & 1388 & 僕 & 128 & 1438 & 弥 & 11 & 1488 & 悔 & 972 \\
\hline 1239 & 柔 & 349 & 1289 & 剣 & 1641 & 1339 & 往 & 1483 & 1389 & 疲 & 1267 & 1438 & 概 & 1111 & 1489 & 釗 & 970 \\
\hline 1240 & 繁 & 842 & 1290 & 摩 & 1640 & 1340 & 系 & 1482 & 1390 & 擁 & 1264 & 1440 & 秀 & 1110 & 1490 & 婏 & 968 \\
\hline 1241 & 麻 & & 1290 & 砲 & 1640 & 1341 & 曾 & 148 & 1391 & 悟 & 1257 & 1441 & 剛 & 1107 & 1491 & 肺 & 964 \\
\hline 1242 & 滋 & 1 & 1290 & $\mp$ & 1640 & 1342 & 卵 & 147 & 1392 & 恩 & 1256 & 1442 & 銘 & 1102 & 1492 & 媛 & 963 \\
\hline 1243 & 肩 & 1825 & 1293 & 敵 & 1639 & 1343 & 聖 & 1476 & 1392 & 憶 & 1256 & 1443 & 掃 & 1094 & 1492 & 暇 & 963 \\
\hline 1244 & 徆 & 1819 & 1294 & 珍 & 1637 & 1344 & 檚 & 147 & 1394 & 皆 & 125 & 1444 & 缶 & 1086 & 1494 & 嵐 & 959 \\
\hline 1245 & 腕 & 1804 & 1295 & 栃 & 1631 & 1345 & 絞 & 1471 & 1395 & 誇 & 1254 & 1445 & 耕 & 108 & 1495 & 跳 & 958 \\
\hline 1246 & 貫 & 1802 & 1296 & 慜 & 1626 & 1346 & 㴿 & 1456 & 1396 & 孫 & 1253 & 1446 & 霊 & 108 & 1496 & 脈 & 957 \\
\hline 1247 & 腹 & 1799 & 1296 & 錦 & 1626 & 1347 & 偏 & 1449 & 1397 & 殊 & 1246 & 1446 & 陶 & 108 & 1497 & 过 & 954 \\
\hline 1248 & 朗 & 1788 & 1298 & 稼 & 1625 & 1348 & 貧 & 1447 & 1398 & 溶 & 1231 & 1448 & 脇 & 1078 & 1498 & 柴 & 953 \\
\hline 1249 & 撲 & 1785 & 1299 & 罰 & 1623 & 1349 & 遇 & 1437 & 1399 & 軟 & 1228 & 1449 & 伏 & 1077 & 1498 & 隔 & 953 \\
\hline 1250 & 隇 & 1779 & 1300 & 縁 & 1622 & 1350 & 漏 & 1435 & 1400 & 寞 & 1223 & 1450 & 熟 & 1076 & 1500 & 宩 & 948 \\
\hline $\mathrm{CF}$ & & .1912 & $\mathrm{CF}$ & & 97.5529 & CF & & 97.8808 & CF & & 98.1645 & CF & & 8.4101 & $\mathrm{CF}$ & & 3.6258 \\
\hline
\end{tabular}


APPENDIX A (Continued)

\begin{tabular}{|c|c|c|c|c|c|c|c|c|c|c|c|c|c|c|c|c|c|}
\hline & & & & & & & & & & & & & & & & & \\
\hline $\mathrm{R}$ & $\mathrm{C}$ & $\Gamma$ & $\mathrm{R}$ & $\mathrm{C}$ & $\bar{F}$ & $\mathrm{R}$ & $\mathrm{C}$ & $\bar{F}$ & $\mathrm{R}$ & $\mathrm{C}$ & $F$ & $\mathbf{R}$ & $\mathrm{C}$ & $F$ & $\mathbf{R}$ & $\mathrm{C}$ & $\mathrm{F}$ \\
\hline 1501 & 滕 & 943 & 1551 & 翔 & $\overline{818}$ & 1601 & 冠 & 729 & 1650 & 毅 & $\overline{649}$ & 1701 & 呉 & 559 & 1750 & 囉 & 484 \\
\hline 1502 & 栽 & 942 & 1552 & 嘆 & 815 & 1602 & 墨 & 728 & 1652 & 唐 & 648 & 1702 & 机 & 558 & 1750 & 僧 & 484 \\
\hline 1503 & 依 & 940 & 1553 & 衰 & 814 & 1603 & 霖 & 727 & 1653 & 釜 & 645 & 1703 & 尿 & 555 & 1753 & 肢 & 483 \\
\hline 1504 & 奖 & 939 & 1554 & 澤 & 813 & 1604 & 填 & 725 & 1654 & 澄 & 639 & 1704 & 临 & 554 & 1753 & 怪 & 483 \\
\hline 1505 & 秩 & 937 & 1555 & 徐 & 811 & 1605 & 蒸 & 722 & 1655 & 萩 & 636 & 1704 & 霞 & 554 & 1755 & 鍋 & 480 \\
\hline 1506 & 塗 & 936 & 1556 & 靖 & 809 & 1605 & 拾 & 722 & 1656 & 车 & 634 & 1706 & 隅 & 553 & 1756 & 首 & 475 \\
\hline 1507 & 祈 & 935 & 1556 & 懷 & 809 & 1607 & 峰 & 721 & 1656 & 靴 & 634 & 1707 & 朴 & 552 & 1757 & 灘 & 474 \\
\hline 1508 & 菅 & 932 & 1558 & 堺 & 807 & 1608 & 邪 & 719 & 1656 & 勘 & 634 & 1708 & 臭 & 545 & 1757 & 践 & 474 \\
\hline 1508 & 唆 & 932 & 1559 & 粒 & 796 & 1609 & 陵 & 716 & 1659 & 乏 & 632 & 1709 & 猫 & 541 & 1759 & 圭 & 472 \\
\hline 1510 & 随 & 929 & 1560 & 貝 & 793 & 1610 & 艇 & 715 & 1659 & 能道 & 632 & 1710 & 辛 & 540 & 1760 & 鉢 & 469 \\
\hline 1511 & 抽 & 919 & 1561 & 冨 & 792 & 1611 & 鈾 & 714 & 1659 & 吾 & 632 & 1711 & 細 & 539 & 1761 & 吕 & 466 \\
\hline 1512 & 衡 & 917 & 1562 & 逸 & 787 & 1612 & 寮 & 709 & 1662 & 洞 & 628 & 1711 & 悼 & 539 & 1762 & 獣 & 463 \\
\hline 1513 & 据 & 915 & 1563 & 柾 & 786 & 1613 & 泥 & 708 & 1662 & 笹 & 628 & 1711 & 境 & 539 & 1762 & 宴 & 463 \\
\hline 1514 & 斜 & 913 & 1563 & 虐 & 786 & 1614 & 㑭 & 706 & 1664 & 整 & 625 & 1714 & 昇 & 535 & 1764 & 蒲 & 462 \\
\hline 1515 & 桑 & 912 & 1565 & 才 & 784 & 1615 & 棋 & 704 & 1665 & 遭 & 624 & 1714 & 荁 & 535 & 1765 & 鳳 & 461 \\
\hline 1516 & 茫 & 903 & 1566 & 陛 & 782 & 1616 & 亨 & 702 & 1666 & 宜 & 622 & 1716 & 累 & 534 & 1766 & 桃 & 458 \\
\hline 1517 & 鬼 & 902 & 1567 & 刀 & 781 & 1617 & 幻 & 700 & 1667 & 劣 & 618 & 1717 & 特 & 533 & 1767 & 曧 & 456 \\
\hline 1518 & 乾 & 895 & 1567 & 汁 & 781 & 1618 & 坹 & 699 & 1667 & 矛 & 618 & 1717 & 寂 & 533 & 1768 & $乃_{j}$ & 454 \\
\hline 1519 & 仕 & 887 & 1567 & 㥄 & 781 & 1618 & 姓 & 699 & 1669 & 桐 & 615 & 1719 & 赴 & 528 & 1768 & 呈 & 454 \\
\hline 1520 & 粘 & 883 & 1567 & 葛 & 781 & 1618 & 肃 & 699 & 1669 & 芽 & 615 & 1719 & 庙 & 528 & 1770 & 屿 & 453 \\
\hline 1521 & 抨 & 881 & 1571 & 精 & 779 & 1621 & 底郎 & 698 & 1671 & 輔 & 614 & 1719 & 炊 & 528 & 1771 & 裸 & 451 \\
\hline 1522 & 隻 & 876 & 1571 & 准 & 779 & 1622 & 郭 & 695 & 1671 & 碑 & 614 & 1722 & 忍 & 527 & 1771 & 窒 & 451 \\
\hline 1523 & 猛 & 875 & 1573 & 柏 & 778 & 1623 & 妃 & 691 & 1673 & 獄 & 612 & 1723 & 款 & 523 & 1773 & 囚 & 449 \\
\hline 1524 & 漢 & 874 & 1574 & 詐 & 777 & 1623 & 潔 & 691 & 1673 & 峡 & 612 & 1724 & 酷 & 520 & 1774 & 种 & 444 \\
\hline 1525 & 棒 & 873 & 1575 & 俗 & 773 & 1625 & 穏 & 689 & 1675 & 摖 & 611 & 1724 & 荻 & 520 & 1774 & 循 & 444 \\
\hline 1525 & 砕 & 873 & 1576 & 滝 & 770 & 1626 & 悦 & 687 & 1676 & 肌 & 608 & 1726 & 帽 & 519 & 1774 & 綾 & 444 \\
\hline 1527 & 糖 & 868 & 1577 & 酬 & 767 & 1627 & 欺 & 685 & 1677 & 顕 & 606 & 1727 & 亮 & 518 & 1777 & 幣 & 443 \\
\hline 1528 & 架 & 865 & 1578 & 胆 & 766 & 1628 & 灰 & 682 & 1678 & 鎮 & 605 & 1727 & 庶 & 518 & 1778 & 鼓 & 441 \\
\hline 1529 & 改 & 864 & 1579 & 紋 & 764 & 1629 & 磯 & 680 & 1679 & 偶 & 589 & 1727 & 恭 & 518 & 1779 & 該 & 440 \\
\hline 1530 & 脂 & 862 & 1579 & 稚 & 764 & 1630 & 桂 & 679 & 1680 & 把 & 587 & 1730 & 鷹 & 514 & 1780 & 僄 & 439 \\
\hline 1530 & 鋭 & 862 & 1581 & 芦 & 762 & 1631 & 血 & 676 & 1681 & 棬 & 586 & 1730 & 意 & 514 & 1781 & 搭 & 436 \\
\hline 1532 & 盾 & 861 & 1582 & 綿 & 761 & 1632 & 疫 & 675 & 1682 & 坊 & 584 & 1730 & 弦 & 514 & 1782 & 坪 & 434 \\
\hline 1533 & 緯 & 860 & 1582 & 漂 & 761 & 1633 & 伯 & 674 & 1683 & 搬 & 583 & 1733 & 匠 & 513 & 1783 & 漠 & 432 \\
\hline 1534 & 苗 & 858 & 1582 & 㴗 & 761 & 1634 & 跔 & 673 & 1684 & 符 & 582 & 1734 & 金 & 512 & 1783 & 猪 & 432 \\
\hline 1535 & 姫 & 855 & 1585 & 瑞 & 759 & 1635 & 姞 & 671 & 1685 & 敦 & 581 & 1735 & 拐 & 509 & 1783 & 腎 & 432 \\
\hline 1535 & 堤 & 855 & 1586 & 雷 & 758 & 1635 & $|x|$ & 671 & 1686 & 㥬 & 580 & 1736 & 寸 & 508 & 1783 & 飢 & 432 \\
\hline 1537 & 紫 & 854 & 1587 & 奉 & 754 & 1637 & 舟 & 668 & 1686 & 垂 & 580 & 1737 & 夏 & 503 & 1787 & 钱 & 431 \\
\hline 1538 & 銅 & 852 & 1587 & 嫁 & 754 & 1638 & 巧 & 667 & 1686 & 鉛 & 580 & 1738 & 瓶 & 502 & 1787 & 寗 & 431 \\
\hline 1539 & 狂 & 850 & 1589 & 珠 & 753 & 1639 & 酔 & 664 & 1689 & 粗 & 578 & 1739 & 岌 & 496 & 1787 & 朱 & 431 \\
\hline 1540 & 裙 & 847 & 1589 & 眨 & 753 & 1640 & 仰 & 662 & 1690 & 暑 & 574 & 1740 & 諾 & 494 & 1790 & 琶 & 430 \\
\hline 1540 & 勲 & 847 & 1591 & 班 & 751 & 1641 & 晶 & 660 & 1690 & 后 & 574 & 1741 & 函 & 491 & 1791 & 籍 & 429 \\
\hline 1542 & 洲 & 846 & 1592 & 伎 & 750 & 1642 & 湖 & 659 & 1692 & 莘 & 573 & 1742 & 頻 & 490 & 1791 & 憾 & 429 \\
\hline 1543 & 头 & 843 & 1593 & 詞 & 748 & 1643 & 淀 & 656 & 1693 & 塔 & 572 & 1742 & 枯 & 490 & 1793 & 闌 & 425 \\
\hline 1544 & 筥 & 842 & 1594 & 烈 & 747 & 1643 & 膜 & 656 & 1694 & 稳 & 567 & 1744 & 履 & 489 & 1793 & 鴨 & 425 \\
\hline 1545 & 翻 & 838 & 1594 & 堰 & 747 & 1645 & 菓 & 655 & 1694 & 壮 & 567 & 1744 & 槽 & 489 & 1795 & 畠 & 424 \\
\hline 1546 & 淳 & 832 & 1596 & 鎌 & 741 & 1646 & 魔 & 652 & 1694 & 刃 & 567 & 1744 & 閱 & 489 & 1796 & 如 & 423 \\
\hline 1547 & 嘫 & 825 & 1597 & 棚 & 739 & 1646 & 辰 & 652 & 1697 & 絴 & 566 & 1747 & 錯 & 487 & 1797 & 舶 & 419 \\
\hline 1548 & 麦 & 821 & 1598 & 釗 & 735 & 1646 & 涯 & 652 & 1698 & 鳩 & 565 & 1747 & 哉 & 487 & 1798 & 偉 & 418 \\
\hline 1549 & 紡 & 820 & 1599 & 潤 & 734 & 1649 & 謙 & 650 & 1699 & 鐘 & 563 & 1747 & 魂 & 487 & 1799 & 瀖 & 416 \\
\hline 1550 & 軌 & 819 & 1600 & 糟 & 732 & 1650 & 盆 & 649 & 1700 & 弓 & 560 & 1750 & 摩 & 484 & 1800 & 㭤 & 415 \\
\hline$\overline{C F}$ & & 8.8138 & $\mathrm{CF}$ & & 98.9790 & $\mathrm{CF}$ & & 99.1262 & $\mathrm{CF}$ & & 99.2550 & $\mathrm{CF}$ & & 9.3665 & CF & & .4618 \\
\hline
\end{tabular}


APPENDIX A (Continued)

\begin{tabular}{|c|c|c|c|c|c|c|c|c|c|c|c|c|c|c|c|c|c|}
\hline \multirow{2}{*}{$\frac{\mathrm{R}}{1800}$} & \multirow{2}{*}{$\begin{array}{l}\mathrm{C} \\
\text { 騎 }\end{array}$} & $\overline{\mathrm{F}}$ & $\mathrm{R}$ & $\mathrm{C}$ & $\bar{F}$ & $\mathrm{R}$ & C & $F$ & $\mathrm{R}$ & $\bar{C}$ & $F$ & $\mathrm{R}$ & C & $\bar{F}$ & $\bar{R}$ & $\mathrm{C}$ & $F$ \\
\hline & & 415 & 1851 & 嫗 & $\overline{363}$ & 1901 & 窽 & $\overline{302}$ & $195 I$ & 國 & 254 & 2000 & 梁 & $\overline{206}$ & 2049 & 僑 & 169 \\
\hline 1802 & 俸 & 411 & 1852 & 幾 & 360 & 1902 & 摄 & 300 & 1951 & 遮 & 254 & 2002 & 狺 & 204 & 2052 & 电 & 168 \\
\hline 1803 & 樋 & 410 & 1853 & 蛇 & 359 & 1903 & 享 & 299 & 1951 & 傑 & 254 & 2002 & 奔 & 204 & 2053 & 逝 & 167 \\
\hline 1804 & 楠 & 408 & 1854 & 鍛 & 358 & 1904 & 牉 & 295 & 1951 & 茅 & 254 & 2004 & 瘍 & 202 & 2054 & 鳥 & 166 \\
\hline 1804 & 娠 & 408 & 1855 & 枢 & 354 & 1904 & 扶 & 295 & 1955 & 乙 & 252 & 2004 & 型 & 202 & 2055 & 惧 & 165 \\
\hline 1806 & 㳬 & 405 & 1856 & 篤 & 351 & 1904 & 樺 & 295 & 1956 & 喬 & 251 & 2006 & 痢 & 201 & 2056 & 瞩 & 164 \\
\hline 1806 & 殼 & 405 & 1857 & 疾 & 350 & 1907 & 匿 & 293 & 1957 & 睦 & 250 & 2006 & 幔 & 201 & 2057 & 洸 & 163 \\
\hline 1808 & 涼 & 404 & 1857 & 串 & 350 & 1907 & 偵 & 293 & 1957 & 睡 & 250 & 2008 & 諏 & 199 & 2057 & 拫 & 163 \\
\hline 1808 & 腸 & 404 & 1857 & 朽 & 350 & 1907 & 錠 & 293 & 1959 & 廣 & 249 & 2008 & 擬 & 199 & 2059 & 聯 & 162 \\
\hline 1808 & 畜 & 404 & 1860 & 紘 & 348 & 1907 & 渦 & 293 & 1960 & 播 & 248 & 2010 & 吟 & 198 & 2059 & 禛 & 162 \\
\hline 1808 & 鶏 & 404 & 1861 & 憤 & 346 & 1911 & 綝 & 292 & 1960 & 肖 & 248 & 2011 & 潾 & 197 & 2059 & 祗 & 162 \\
\hline 1812 & 粋 & 402 & 1861 & 屝 & 346 & 1912 & 猟 & 288 & 1962 & 絧 & 247 & 2011 & 落 & 197 & 2062 & 薄 & 161 \\
\hline 1812 & 刃 & 402 & 1861 & 柿 & 346 & 1912 & 壊 & 288 & 1963 & 喷 & 246 & 2013 & 悺 & 195 & 2063 & 勅 & 160 \\
\hline 1814 & 虎 & 400 & 1864 & 泡 & 344 & 1914 & 陪 & 287 & 1964 & 胎 & 245 & 2014 & 㻉 & 194 & 2064 & 早 & 159 \\
\hline 1815 & 潘 & 399 & 1864 & 碁 & 344 & 1914 & 甚 & 287 & 1965 & 墪 & 243 & 2015 & 鴻 & 193 & 2064 & 拳 & 159 \\
\hline 1816 & 漬 & 398 & 1866 & 掌 & 340 & 1916 & 塊 & 286 & 1966 & 水 & 241 & 2016 & 開 & 191 & 2066 & 錬 & 157 \\
\hline 1817 & 洪 & 397 & 1867 & 飽 & 334 & 1917 & 㝙 & 285 & 1967 & 忌 & 239 & 2016 & 真 & 191 & 2066 & 硝 & 157 \\
\hline 1818 & 縛 & 396 & 1867 & 伍 & 334 & 1918 & 剖 & 284 & 1968 & 日 & 237 & 2016 & 偷 & 191 & 2068 & 爾 & 156 \\
\hline 1818 & 昆 & 396 & 1869 & 프 & 333 & 1919 & 鹦 & 283 & 1969 & 肯 & 236 & 2016 & 沉 & 191 & 2068 & 扯 & 156 \\
\hline 1818 & 薫 & 396 & 1869 & 事 & 333 & 1919 & 肇 & 283 & 1969 & $x_{i j}$ & 236 & 2016 & 蕉 & 191 & 2070 & 條 & 155 \\
\hline 1821 & 眺 & 395 & 1871 & 是 & 332 & 1921 & 叙 & 282 & 1971 & 遍 & 233 & 2016 & 越 & 191 & 2070 & 逓 & 155 \\
\hline 1821 & 政 & 395 & 1872 & 又 & 329 & 1922 & 塞 & 278 & 1971 & 帆 & 233 & 2022 & 駢 & 190 & 2072 & 庵 & 154 \\
\hline 1823 & 弊 & 389 & 1873 & 践 & 327 & 1922 & 俱 & 278 & 1971 & 琢 & 233 & 2023 & 奴 & 189 & 2073 & 美 & 153 \\
\hline 1824 & 怒 & 388 & 1874 & 悠 & 326 & 1924 & 喝 & 277 & 1974 & 樽 & 230 & 2023 & $\pi$ & 189 & 2073 & 意 & 153 \\
\hline 1825 & 穌 & 385 & 1874 & 貝 & 326 & 1925 & 胴 & 274 & 1975 & 秦 & 228 & 2025 & 芭 & 188 & 2073 & 隼 & 153 \\
\hline 1826 & 郁 & 384 & 1876 & 譜 & 323 & 1925 & 嘱 & 274 & 1976 & 挿 & 225 & 2026 & 厘 & 187 & 2073 & 謎 & 153 \\
\hline 1827 & 蹩 & 383 & 1876 & 酢 & 323 & 1925 & 尺 & 274 & 1977 & 寅 & 223 & 2026 & 此 & 187 & 2077 & 䅠 & 150 \\
\hline 1828 & 沸 & 382 & 1878 & 巴 & 322 & 1928 & 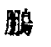 & 272 & 1978 & 薩 & 221 & 2028 & 抹 & 185 & 2078 & 渴 & 149 \\
\hline 1829 & 流 & 380 & 1878 & 曲 & 322 & 1929 & 屯 & 271 & 1978 & 沙 & 221 & 2028 & 欣 & 185 & 2079 & 藍 & 148 \\
\hline 1830 & 衰 & 379 & 1880 & 韦 & 321 & 1929 & 圥 & 271 & 1978 & 敢 & 221 & 2028 & 閑 & 185 & 2079 & 橿 & 148 \\
\hline 1831 & 凡 & 377 & 1880 & 憎 & 321 & 1931 & 箕 & 269 & 1981 & 满 & 219 & 2028 & 禍 & 185 & 2081 & 雀 & 146 \\
\hline 1831 & 柣 & 377 & 1882 & 餓 & 320 & 1931 & 朋 & 269 & 1982 & 屏 & 217 & 2032 & 漱 & 183 & 2081 & 潰 & 146 \\
\hline I83I & 扇 & 377 & 1883 & 笛 & 319 & 1931 & 亨 & 269 & 1982 & 舘 & 217 & 2032 & 暢 & 183 & 2081 & 栈 & 146 \\
\hline 1834 & 慈 & 376 & 1883 & 挟 & 319 & 1934 & 硫 & 268 & 1984 & 笔 & 216 & 2032 & 侍 & 183 & 2081 & 椫 & 146 \\
\hline 1835 & 伐 & 374 & 1885 & 凝 & 316 & 1934 & 溹 & 268 & 1984 & 粕 & 216 & 2032 & 代 & 183 & 2085 & 孃 & 142 \\
\hline 1836 & 蓮 & 373 & 1886 & 瓦 & 315 & 1934 & 樗 & 268 & 1984 & 斗 & 216 & 2036 & 荅 & 182 & 2086 & 蛍 & 141 \\
\hline 1836 & 巳 & 373 & 1886 & 慨 & 315 & 1937 & 盧 & 267 & 1987 & 劉 & 214 & 2036 & 渓 & 182 & 2087 & 隷 & 140 \\
\hline 1838 & 港 & 372 & 1888 & 㮩 & 314 & 1937 & 汽 & 267 & 1987 & 楊 & 214 & 2038 & 紏 & 181 & 2087 & 愁 & 140 \\
\hline 1839 & 椎 & 371 & 1889 & 豚 & 312 & 1939 & 坑 & 266 & 1989 & 佑 & 213 & 2039 & 粕 & 180 & 2089 & 腺 & 139 \\
\hline 1839 & 濁 & 371 & 1890 & 窎 & 311 & 1940 & 栖 & 265 & 1990 & 鉃 & 212 & 2040 & 滴 & 179 & 2089 & 獅 & 139 \\
\hline 1839 & 燥 & 371 & 1890 & 挫 & 311 & 1940 & 駿 & 265 & 1990 & 禅 & 212 & 2041 & 胡 & 176 & $209 \mathrm{I}$ & 遼 & 138 \\
\hline 1842 & 媒 & 370 & 1892 & 榉 & 310 & 1942 & 楼 & 264 & 1990 & 腫 & 212 & 2041 & 茎 & 176 & 2091 & 珂 & 138 \\
\hline 1842 & 奄 & 370 & 1892 & 倊 & 310 & 1943 & 楆 & 263 & 1993 & 梇 & 210 & 2043 & 鍵 & 175 & 2091 & 鞍 & 138 \\
\hline 1844 & 禁 & 369 & 1894 & 同 & 309 & 1943 & 唄 & 263 & 1994 & 湘 & 209 & 2044 & 尉 & 173 & 2094 & 唯 & 137 \\
\hline 1845 & 愚 & 368 & 1895 & 淑 & 308 & 1945 & 嗯 & 262 & 1995 & 玲 & 208 & 2045 & 杵 & 172 & 2095 & 婧 & 136 \\
\hline 1846 & 苫 & 367 & 1895 & 恨 & 308 & 1945 & 酮 & 262 & 1995 & 羊 & 208 & 2045 & 翁 & 172 & 2095 & 枕 & 136 \\
\hline 1847 & 嶺 & 366 & 1897 & 崇 & 307 & 1947 & 廉 & 258 & 1995 & 䦣 & 208 & 2047 & 流 & 171 & 2095 & 姑 & 136 \\
\hline 1848 & 酵 & 365 & 1898 & 礁 & 305 & 1948 & 舽 & 256 & 1998 & 肪 & 207 & 2048 & 匡 & 170 & 2095 & 斡 & 136 \\
\hline 1848 & 犗 & 365 & 1899 & 斐 & 303 & 1949 & 雀 & 255 & 1998 & 侩 & 207 & 2049 & 迅 & 169 & 2099 & 畔 & 135 \\
\hline 1850 & 晋 & 364 & 1899 & 舌 & 303 & 1949 & 款 & 255 & 2000 & 趋 & 206 & 2049 & 塞 & 169 & 2099 & 袖 & 135 \\
\hline $\mathrm{CF}$ & & $\overline{5445}$ & $\mathrm{CF}$ & & .6146 & CF & & .6736 & $\mathrm{CF}$ & & 7226 & $\mathrm{CF}$ & & .7627 & $\mathrm{CF}$ & & 9.7953 \\
\hline
\end{tabular}


APPENDIX A (Continued)

\begin{tabular}{|c|c|c|c|c|c|c|c|c|c|c|c|c|c|c|c|c|c|}
\hline $\mathrm{R}$ & $\mathrm{C}$ & $F$ & $\mathrm{R}$ & $\mathrm{C}$ & $F$ & $\mathrm{R}$ & $\mathrm{C}$ & $\mathrm{F}$ & $\mathbf{R}$ & C & $\mathrm{F}$ & $\mathbf{R}$ & C & $F$ & $R$ & $\mathrm{C}$ & $\mathrm{F}$ \\
\hline 2099 & 铙 & 135 & 2150 & 梄 & 112 & 2200 & 堆 & 95 & 2249 & 廠 & 79 & 2298 & 爵 & 67 & $235 I$ & 蹊 & 59 \\
\hline 2099 & 孔 & 135 & 2152 & 租 & 111 & 2200 & 櫛 & 95 & 2249 & 娟 & 79 & 2298 & 汐 & 67 & 2351 & 賦 & 59 \\
\hline 2103 & 妖 & 134 & 2152 & 斥 & 111 & 2203 & 脊 & 94 & 2253 & 諾柬 & 78 & 2298 & 矩 & 67 & 2351 & 枇 & 59 \\
\hline 2103 & 栓 & 134 & 2152 & 触 & 111 & 2203 & 稽 & 94 & 2253 & 褐 & 78 & 2298 & 欽 & 67 & $235 I$ & 海 & 59 \\
\hline 2705 & 捂 & 133 & 2152 & 允 & 111 & 2205 & 偠 & 93 & 2253 & 牙 & 78 & 2305 & 礒 & 66 & 2351 & 挺 & 59 \\
\hline 2105 & 呆 & 133 & 2156 & 涛 & 110 & 2205 & 佃 & 93 & 2256 & 蜜 & 77 & 2305 & 疆 & 66 & 2351 & 帥 & 59 \\
\hline 2105 & 絴 & 133 & 2156 & 賭 & 110 & 2207 & 雁 & 92 & 2256 & 杷 & 77 & 2305 & 侣 & 66 & 2351 & 叱 & 59 \\
\hline 2105 & 拙 & 133 & 2156 & 末 & 110 & 2207 & 旺 & 92 & 2256 & 榛 & 77 & 2305 & 隐 & 66 & 2351 & 封 & 59 \\
\hline 2105 & 襟 & 133 & 2159 & 㵑 & 109 & 2209 & 撃 & 91 & 2256 & 鳴 & 77 & 2305 & 患 & 66 & 2351 & 閤 & 59 \\
\hline 2110 & 庸 & 132 & 2160 & 策 & 108 & 2209 & 針 & 91 & 2260 & 邨 & 76 & 2310 & 邱 & 65 & 2351 & 狐 & 59 \\
\hline 2110 & 粟 & 132 & 2160 & 酥 & 108 & 2209 & 箬 & 91 & 2260 & 綜 & 76 & 2310 & 焉 & 65 & 2351 & 唫 & 59 \\
\hline 2112 & 萬 & 131 & 2162 & 侮 & 107 & 2212 & 逐 & 90 & 2260 & 漕 & 76 & 2310 & 妄 & 65 & 2351 & 凯 & 59 \\
\hline 2112 & 其 & 131 & 2162 & 峻 & 107 & 2213 & 實 & 89 & 2260 & 饎 & 76 & 2310 & 鋪 & 65 & 2351 & 芋 & 59 \\
\hline 2114 & 虾. & 130 & 2164 & 槒 & 106 & 2213 & 芙 & 89 & 2260 & 迦 & 76 & 2310 & 蕃 & 65 & 2364 & 汪 & 58 \\
\hline $21 / 4$ & 杜 & 130 & 2165 & 龽 & 105 & 2213 & 能 & 89 & 2265 & 鎔 & 75 & 2310 & 檀 & 65 & 2364 & 蓝 & 58 \\
\hline 2116 & 餅 & 129 & 2165 & 禄 & 105 & 2213 & 銚 & 89 & 2265 & 麓 & 75 & 2310 & 惰 & 65 & 2364 & 㐜 & 58 \\
\hline 2116 & 迭 & 129 & 2167 & 喗 & 104 & 2213 & 捉 & 89 & 2265 & 叕 & 75 & 2317 & 董 & 64 & 2364 & 旦 & 58 \\
\hline 2118 & 哨 & 128 & 2167 & 壽 & 104 & 2213 & 采 & 89 & 2265 & 娂 & 75 & 2317 & 伽 & 64 & 2364 & 倝 & 58 \\
\hline 2118 & 讙 & 128 & 2167 & 薮 & 104 & 2219 & 萌 & 88 & 2265 & 桶 & 75 & 2319 & 笘 & 63 & 2369 & 諫 & 57 \\
\hline 2120 & 泌 & 127 & 2167 & 孟 & 104 & 2219 & 逗 & 88 & 2270 & 脩 & 74 & 2319 & 冤 & 63 & 2369 & 舵 & 57 \\
\hline 2121 & 蛭 & 126 & 2167 & 賊 & 104 & 2219 & 讀 & 88 & 2271 & 菩 & 73 & 2319 & 㥉 & 63 & 2369 & 狛 & 57 \\
\hline 2122 & 渥 & 124 & 2167 & 唇 & 104 & 2219 & 路 & 88 & 2271 & 埴 & 73 & 2319 & 曈 & 63 & 2369 & 杭 & 57 \\
\hline 2123 & 祀 & 122 & 2167 & 玩 & 104 & 2223 & 鐸 & 87 & 2271 & 錫 & 73 & 2319 & 戴 & 63 & 2373 & 称 & 56 \\
\hline 2123 & 幽 & 122 & 2174 & 瑠 & 103 & 2223 & 凹 & 87 & 2274 & 潘 & 72 & 2319 & 増 & 63 & 2373 & 堵 & 56 \\
\hline 2125 & 蝶 & 120 & 2174 & 霜 & 103 & 2223 & 葵 & 87 & 2274 & 壕 & 72 & 2319 & 卿 & 63 & 2373 & 帖 & 56 \\
\hline 2125 & 澈 & 120 & 2174 & 芹 & 103 & 2226 & 檜 & 86 & 2274 & 㺵 & 72 & 2326 & 魯 & 62 & 2373 & 畧 & 56 \\
\hline 2127 & 稜 & 119 & 2174 & 暿 & 103 & 2226 & 琌 & 86 & 2277 & 暈 & 71 & 2326 & 滗 & 62 & 2373 & 碓 & 56 \\
\hline 2127 & 蜂 & 119 & 2174 & 蚊 & 103 & 2226 & 賜 & 86 & 2277 & 詣 & 71 & 2326 & 勾 & 62 & 2373 & 梓 & 56 \\
\hline 2129 & 碧 & 118 & 2179 & 魏 & 102 & 2226 & 溒 & 86 & 2277 & 於 & 71 & 2326 & 芯 & 62 & 2379 & 壶 & 55 \\
\hline 2130 & 叔 & 117 & 2179 & 眉 & 102 & 2226 & 㻏 & 86 & 2277 & 杏 & 71 & 2326 & 抄 & 62 & 2379 & 篭 & 55 \\
\hline 2130 & 酌 & 117 & 2179 & 宾 & 102 & 2231 & 拷 & 85 & 2281 & 堯 & 70 & 2326 & 儒 & 62 & 2379 & 某 & 55 \\
\hline 2130 & 兒 & 117 & 2182 & 彬 & 101 & 2231 & 暂 & 85 & 2281 & 尹 & 70 & 2326 & 所 & 62 & 2379 & 鋒 & 55 \\
\hline 2130 & 姐 & 117 & 2182 & 虽 & 101 & 2233 & 湧 & 84 & 2281 & 汰 & 70 & 2326 & 頃 & 62 & 2379 & 称 & 55 \\
\hline 2134 & 洛 & 116 & 2182 & 踥 & 101 & 2234 & 倩 & 83 & 2281 & 惣 & 70 & 2326 & 蓋 & 62 & 2379 & 艶 & 55 \\
\hline 2134 & 頓 & 116 & 2185 & 慧 & 100 & 2235 & 嗀 & 82 & 2281 & 侗 & 70 & 2326 & 㖇 & 62 & 2385 & 賈 & 54 \\
\hline 2134 & 零 & 116 & 2186 & 斑 & 99 & 2235 & 圓 & 82 & 2281 & 鲭 & 70 & 2336 & 團 & 61 & 2385 & 浙 & 54 \\
\hline 2134 & 湂 & 116 & 2186 & 巽 & 99 & 2235 & 椋 & 82 & 2287 & 儤 & 69 & 2336 & 點 & 61 & 2385 & 拉 & 54 \\
\hline 2134 & 壱 & 116 & 2186 & 㩁 & 99 & 2235 & 㹂 & 82 & 2287 & 杖 & 69 & 2336 & 弄 & 61 & 2385 & 麵 & 54 \\
\hline 2139 & 耗 & 115 & 2186 & 股 & 99 & 2235 & 陀 & 82 & 2289 & 暲 & 68 & 2336 & 瞭 & 61 & 2385 & 陊 & 54 \\
\hline 2139 & 媆 & 115 & 2186 & 逢 & 99 & 2235 & 㫛 & 82 & 2289 & 皓 & 68 & 2336 & 绝 & 61 & 2385 & 篇 & 54 \\
\hline 2139 & 蟹 & 115 & 2191 & 罙 & 98 & 2235 & 侯 & 82 & 2289 & 煩 & 68 & 2336 & 治 & 61 & 2385 & 菲 & 54 \\
\hline 2139 & 燕 & 115 & 2191 & 堪 & 98 & 2235 & 觡 & 82 & 2289 & 埜 & 68 & 2336 & 婆 & 61 & 2385 & 棳 & 54 \\
\hline 2143 & 升 & 114 & 2191 & 政 & 98 & 2243 & 嵯 & 81 & 2289 & 宵 & 68 & 2336 & 痘 & 61 & 2385 & 鋅 & 54 \\
\hline 2143 & 殉 & 114 & 2194 & 貌 & 97 & 2243 & 憼 & 81 & 2289 & 䍭 & 68 & 2336 & 綬 & 61 & 2385 & 狗 & 54 \\
\hline 2143 & 雌 & 114 & 2195 & 厄 & 96 & 2243 & 峨 & 81 & 2289 & 船 & 68 & 2336 & 鮫 & 61 & 2385 & 韻 & 54 \\
\hline 2143 & 特 & 114 & 2195 & 蒙 & 96 & 2243 & 雀 & 81 & 2289 & 教 & 68 & 2336 & 惟 & 61 & 2396 & 佛 & 53 \\
\hline 2147 & 凸 & 113 & 2195 & 磨 & 96 & 2247 & 附 & 80 & 2289 & 蔁 & 68 & 2347 & 㮡 & 60 & 2396 & 䒽 & 53 \\
\hline 2147 & 嫡 & 113 & 2195 & 拭 & 96 & 2247 & 鍾 & 80 & 2298 & 黎 & 67 & 2347 & 恣 & 60 & 2396 & 廟 & 53 \\
\hline 2147 & 翠 & 113 & 2195 & 真 & 96 & 2249 & 缶 & 79 & 2298 & 狼 & 67 & 2347 & 做 & 60 & 2396 & 酉 & 53 \\
\hline 2150 & 籠 & 112 & 2200 & 甫 & 95 & 2249 & 啄 & 79 & 2298 & 柘 & 67 & 2347 & 炎 & 60 & 2400 & 霜 & 52 \\
\hline $\mathrm{CF}$ & & 99.8220 & $\mathrm{CF}$ & & 8434 & $\mathrm{CF}$ & & 99.8626 & $\mathrm{CF}$ & & 99.8776 & $\mathrm{CF}$ & & 8926 & $\mathrm{CF}$ & & 9039 \\
\hline
\end{tabular}


APPENDIX A (Continued)

\begin{tabular}{|c|c|c|c|c|c|c|c|c|c|c|c|c|c|c|c|c|c|}
\hline $\mathrm{R}$ & C & $F$ & $\mathrm{~K}$ & $C$ & $F$ & $\mathrm{R}$ & $\mathrm{C}$ & $\mathrm{F}$ & $\mathrm{R}$ & $\mathrm{C}$ & $\mathrm{F}$ & $\mathrm{R}$ & $\mathrm{C}$ & $\mathrm{F}$ & $\mathrm{R}$ & $\mathrm{C}$ & $\mathrm{F}$ \\
\hline 2400 & $\overline{\mathrm{E}}$ & 52 & 2449 & 螉 & 46 & 2496 & 瓜 & $\overline{40}$ & 2543 & 耶 & $\overline{35}$ & 2599 & 蔡 & 31 & 2646 & 惠 & 28 \\
\hline 2402 & 筀 & 51 & 2449 & 婏 & 46 & 2496 & 閽 & 40 & 2543 & 勡 & 35 & 2599 & 洗 & 31 & 2646 & 彭 & 28 \\
\hline 2402 & 晟 & 51 & 2449 & 沌 & 46 & 2503 & 彗 & 39 & 2543 & 燈 & 35 & 2599 & 整 & 31 & 2646 & 咸 & 28 \\
\hline 2402 & 溜 & 51 & 2449 & 悌 & 46 & 2503 & 牌 & 39 & 2543 & 溺 & 35 & 2599 & 帮 & 31 & 2646 & 偕 & 28 \\
\hline 2402 & 容 & 51 & 2449 & 諜 & 46 & 2503 & 醍 & 39 & 2543 & 鯛 & 35 & 2599 & 凰 & 31 & 2646 & 傭 & 28 \\
\hline 2402 & 舆 & 51 & 2449 & 坦 & 46 & 2503 & 望 & 39 & 2543 & 楚 & 35 & 2599 & 麟 & 31 & 2646 & 粪 & 28 \\
\hline 2402 & 䴢 & 51 & 2449 & 只 & 46 & 2503 & 漱 & 39 & 2543 & 蝉 & 35 & 2599 & 爺 & 31 & 2646 & 釗 & 28 \\
\hline 2402 & 承 & 51 & 2449 & 叨 & 46 & 2503 & 㯴 & 39 & 2543 & 稀 & 35 & 2599 & 膿 & 31 & 2646 & 葛 & 28 \\
\hline 2402 & 昏 & 51 & 2459 & 船 & 45 & 2503 & 柴 & 39 & 2559 & 筆 & 34 & 2599 & 廿 & 31 & 2646 & 蜘 & 28 \\
\hline 2402 & 梗 & 51 & 2459 & 讶 & 45 & 2503 & 醐 & 39 & 2559 & 禮 & 34 & 2599 & 凩 & 31 & 2646 & 叒 & 28 \\
\hline 2411 & 褧 & 50 & 2459 & 袎 & 45 & 2503 & 沓 & 39 & 2559 & 拗 & 34 & 2599 & 脆 & 31 & 2646 & 絃 & 28 \\
\hline 2411 & 薮 & 50 & 2459 & 崖 & 45 & $25 / 2$ & 迪 & 38 & 2559 & 傲 & 34 & 2599 & 雛 & 31 & 2646 & 仇 & 28 \\
\hline 2411 & 萋 & 50 & 2459 & 云 & 45 & 2512 & 虔 & 38 & 2559 & 唾 & 34 & 2599 & 梱 & 31 & 2646 & 咽 & 28 \\
\hline $2+11$ & 但 & 50 & 2464 & 动 & 44 & 2512 & 腱 & 38 & 2559 & 捷 & 34 & 2599 & 昂 & 31 & 2664 & 琿 & 27 \\
\hline 2411 & 檜 & 50 & 2464 & 勃 & 44 & 2512 & 洽 & 38 & 2559 & 踃 & 34 & 2599 & 姶 & 31 & 2664 & 殷 & 27 \\
\hline 2411 & 欴 & 50 & 2464 & 猚 & 44 & 2512 & 櫻 & 38 & 2559 & 硯 & 34 & 2616 & 䇺 & 30 & 2664 & 杞 & 27 \\
\hline 2411 & 将 & 50 & 2464 & 变 & 44 & 2512 & 姪 & 38 & 2559 & 飴 & 34 & 2616 & 筌 & 30 & 2664 & 揄 & 27 \\
\hline 2411 & 紗 & 50 & 2468 & 井 & 43 & 2512 & 鱒 & 38 & 2568 & 綺 & 33 & 2616 & 権 & 30 & 2664 & 揶 & 27 \\
\hline 2411 & 縞 & 50 & 2468 & 歪 & 43 & 2512 & 罵 & 38 & 2568 & 昂 & 33 & 2616 & 涵 & 30 & 2664 & 罹 & 27 \\
\hline 2411 & 盆 & 50 & 2468 & 渚 & 43 & 2512 & 樟 & 38 & 2568 & 椧 & 33 & 2616 & 濫 & 30 & 2664 & 固 & 27 \\
\hline 2411 & 夷 & 50 & 2468 & 坐 & 43 & 2512 & 棚 & 38 & 2568 & 瀕 & 33 & 2616 & 斌 & 30 & 2664 & 㫮 & 27 \\
\hline 2422 & 幒 & 49 & 2468 & 訣 & 43 & 2512 & 腔 & 38 & 2568 & 剥 & 33 & 2616 & 庇 & 30 & 2664 & 俑 & 27 \\
\hline 2422 & 洙 & 49 & 2468 & 怨 & 43 & 2512 & 巷 & 38 & 2568 & 妚 & 33 & 2616 & 堭 & 30 & 2664 & 牛 & 27 \\
\hline 2422 & 捺 & 49 & 2468 & 墟 & 43 & 2512 & 喉 & 38 & 2568 & 梯 & 33 & 2616 & 壬 & 30 & 2664 & 彪 & 27 \\
\hline 2422 & 宕 & 49 & 2475 & 萧 & 42 & 2512 & 鞠 & 38 & 2568 & 椐 & 33 & 2616 & 蛙 & 30 & 2664 & 套 & 27 \\
\hline 2422 & 鬼 & 49 & 2475 & 毩 & 42 & 2512 & 俺 & 38 & 2568 & 禽 & 33 & 2616 & 厩 & 30 & 2664 & 捗 & 27 \\
\hline 2422 & 酎 & 49 & 2475 & 唼 & 42 & 2527 & 㱍 & 37 & 2568 & 梢 & 33 & 2616 & 或 & 30 & 2664 & 佼 & 27 \\
\hline 2422 & 湛 & 49 & 2475 & 碗 & 42 & 2527 & 嘲 & 37 & 2568 & 漉 & 33 & 2616 & 茜 & 30 & 2664 & 袈 & 27 \\
\hline 2422 & 爽 & 49 & 2475 & 鱗 & 42 & 2527 & 賂 & 37 & 2568 & 寓 & 33 & 2629 & 盖 & 29 & 2664 & 妄 & 27 \\
\hline 2422 & 菥 & 49 & 2475 & 莫 & 42 & 2527 & 呑 & 37 & 2568 & 喰 & 33 & 2629 & 率 & 29 & 2664 & 虹 & 27 \\
\hline 2422 & 絢 & 49 & 2475 & 滕 & 42 & 2527 & 填 & 37 & 2581 & 章 & 32 & 2629 & 啮 & 29 & 2681 & 䩫 & 26 \\
\hline 2432 & 絆 & 48 & 2475 & 部 & 42 & 2527 & 舛 & 37 & 2581 & 笙 & 32 & 2629 & 曼 & 29 & 2681 & 蛯 & 26 \\
\hline 2432 & 脰 & 48 & 2475 & 摺 & 42 & 2533 & 濶 & 36 & 2581 & 揆 & 32 & 2629 & 珠 & 29 & 2681 & 薇 & 26 \\
\hline 2432 & 樦 & 48 & 2475 & 嘗 & 42 & 2533 & 福 & 36 & 2581 & 拮 & 32 & 2629 & 濡 & 29 & 2681 & 茫 & 26 \\
\hline 2432 & 㩏 & 48 & 2475 & 戎 & 42 & 2533 & 詫 & 36 & 2581 & 峙 & 32 & 2629 & 苟 & 29 & 2681 & 筰 & 26 \\
\hline 2432 & 詔 & 48 & 2486 & 鋮 & 41 & 2533 & 更 & 36 & 2581 & 們 & 32 & 2629 & 叢 & 29 & 2681 & 䀧 & 26 \\
\hline 2432 & 喧 & 48 & 2486 & 逶 & 41 & 2533 & 涌 & 36 & 2581 & 螺 & 32 & 2629 & 棲 & 29 & 2681 & 嗥 & 26 \\
\hline 2432 & 析 & 48 & 2486 & 茨 & 41 & 2533 & 芠 & 36 & 2581 & 牝 & 32 & 2629 & 錗 & 29 & 2681 & 掟 & 26 \\
\hline 2432 & 营 & 48 & 2486 & 噺 & 41 & 2533 & 汀 & 36 & 2581 & 味 & 32 & 2629 & 葛 & 29 & 2681 & 耑 & 26 \\
\hline 2440 & 頸 & 47 & 2486 & 娼 & 41 & 2533 & 碩 & 36 & 2581 & 丙 & 32 & 2629 & 偲 & 29 & 2681 & 㖦 & 26 \\
\hline 2440 & 與 & 47 & 2486 & 敕 & 41 & 2533 & 藯 & 36 & 2581 & 挽 & 32 & 2629 & 纂 & 29 & 2681 & 㝨 & 26 \\
\hline 2440 & 旛 & 47 & 2486 & 弧 & 41 & 2533 & 箇 & 36 & 2581 & 莫 & 32 & 2629 & 拸 & 29 & 2681 & 吠 & 26 \\
\hline 2470 & 捧 & 47 & 2486 & 畦 & 41 & 2543 & 雉 & 35 & 2581 & 䟽 & 32 & 2629 & 庚 & 29 & 2681 & 憧 & 26 \\
\hline 2440 & 舞 & 47 & 2486 & 漟 & 41 & 2543 & 篻 & 35 & 2581 & 夙 & 32 & 2629 & 茄 & 29 & 2681 & 砥 & 26 \\
\hline 2440 & 而 & 47 & 2486 & 井 & 41 & 2543 & 禹 & 35 & 2581 & 辏 & 32 & 2629 & 挨 & 29 & 2681 & 撰 & 26 \\
\hline 2440 & 倹 & 47 & 2496 & 和 & 40 & 2543 & 檄 & 35 & 2581 & 梠 & 32 & 2646 & 蛛 & 28 & 2681 & 䞮 & 26 \\
\hline 2440 & 穎 & 47 & 2496 & 䋊 & 40 & 2543 & 楸 & 35 & 2581 & 蚑 & 32 & 2646 & 养 & 28 & 2681 & 然 & 26 \\
\hline 2440 & 喓 & 47 & 2496 & 専 & 40 & 2543 & 耕 & 35 & 2581 & 畏 & 32 & 2646 & 炣 & 28 & 2681 & 后 & 26 \\
\hline 2449 & 釉 & 46 & 2496 & 砺 & 40 & 2543 & 藏 & 35 & 2599 & 袁 & 31 & 2646 & 溥 & 28 & 2681 & 伕 & 26 \\
\hline 2449 & 諧 & 46 & 2496 & 迴 & 40 & 2543 & 龇 & 35 & 2599 & 葧 & 31 & 2646 & 勏 & 28 & 2681 & 砧 & 26 \\
\hline $\mathrm{CF}$ & & 99.9139 & $\mathrm{CF}$ & & 99.9239 & $\mathrm{CF}$ & & 99.9331 & $\mathrm{CF}$ & & 9.9381 & $\mathrm{CF}$ & & 9.9431 & $\mathrm{CF}$ & & 99.9481 \\
\hline
\end{tabular}


APPENDIX A (Continued)

\begin{tabular}{|c|c|c|c|c|c|c|c|c|c|c|c|c|c|c|c|c|c|}
\hline & & & & & & & & & & & & & & & & & \\
\hline $\mathrm{R}$ & $C$ & $\mathrm{~F}$ & $\mathrm{R}$ & $c$ & $F$ & $\mathrm{R}$ & $\mathrm{C}$ & $\bar{F}$ & $\mathrm{R}$ & $\mathrm{C}$ & $F$ & $\mathrm{R}$ & $\mathrm{C}$ & $F$ & $\begin{array}{c}\mathrm{R} \\
\end{array}$ & $\mathrm{C}$ & $F$ \\
\hline 2681 & 卧 & 26 & 2725 & 穎 & $\overline{24}$ & 2785 & 羡 & 21 & 2836 & 柊 & 19 & 2886 & 遜 & 17 & $293 !$ & 淋 & 15 \\
\hline 2702 & 陝 & 25 & 2752 & 遗 & 23 & 2785 & 礉 & 21 & 2836 & 鉛 & 19 & 2886 & 惹 & 17 & 2931 & 悶 & 15 \\
\hline 2702 & 鐵 & 25 & 2752 & 硅 & 23 & 2785 & 棣 & 21 & 2836 & 貼 & 19 & 2886 & 忽 & 17 & 2931 & 蕗 & 15 \\
\hline 2702 & 訾 & 25 & 2752 & 溪 & 23 & 2785 & 叶 & 21 & 2836 & 紬 & 19 & 2886 & 䟢 & 17 & 2931 & 鏑 & 15 \\
\hline 2702 & 踖 & 25 & 2752 & 棹 & 23 & 2785 & 特 & 21 & 2836 & 謏 & 19 & 2886 & 离 & 17 & 2931 & 鹤 & 15 \\
\hline 2702 & 謨 & 25 & 2752 & 暖 & 23 & 2806 & 钓 & 20 & 2836 & 鴫 & 19 & 2886 & 誼 & 17 & 2931 & 耽 & 15 \\
\hline 2702 & 訃 & 25 & 2752 & 慄 & 23 & 2806 & 胚 & 20 & 2836 & 碕 & 19 & 2907 & 靡 & 16 & 2931 & 蛸 & 15 \\
\hline 2702 & 蓝 & 25 & 2752 & 寇 & 23 & 2806 & 總 & 20 & 2836 & 虐 & 19 & 2907 & 䫘 & 16 & 2931 & 蹟 & 15 \\
\hline 2702 & HI & 25 & 2752 & 勁 & 23 & 2806 & 筝 & 20 & 2836 & 巾 & 19 & 2907 & 躬 & 16 & 2931 & 妾 & 15 \\
\hline 2702 & 渾 & 25 & 2752 & 侑 & 23 & 2806 & 矮 & 20 & 2836 & 駕 & 19 & 2907 & 䪷 & 16 & 2931 & 竣 & 15 \\
\hline 2702 & 泄 & 25 & 2752 & 熟 & 23 & 2806 & 瞒 & 20 & 2861 & 鲶 & 18 & 2907 & 蟫 & 16 & 2931 & 勾 & 15 \\
\hline 2702 & 斂 & 25 & 2752 & 策 & 23 & 2806 & 延 & 20 & 2861 & 䩒 & 18 & 2907 & 糺 & 16 & 2931 & 糊 & 15 \\
\hline 2702 & 哈 & 25 & 2752 & 苓 & 23 & 2806 & 珀 & 20 & 2861 & 魔 & 18 & 2907 & 秉 & 16 & 2931 & 釾 & 15 \\
\hline 2702 & 唩 & 25 & 2752 & 頬 & 23 & 2806 & 游 & 20 & 2861 & 茶 & 18 & 2907 & 猥 & 16 & 2931 & 虾 & 15 \\
\hline 2702 & 珷 & 25 & 2752 & 鞭 & 23 & 2806 & 哳 & 20 & 2861 & 綵 & 18 & 2907 & 㙨 & 16 & 2931 & 苛 & 15 \\
\hline 2702 & 䊼 & 25 & 2752 & 疋 & 23 & 2806 & 雙 & 20 & 2861 & 筧 & 18 & 2907 & 机 & 16 & 2966 & 裔 & 14 \\
\hline 2702 & 㤽 & 25 & 2752 & 琵 & 23 & 2806 & 颌 & 20 & 2861 & 䭲 & 18 & 2907 & 睬 & 16 & 2966 & 蟇 & 14 \\
\hline 2702 & 调 & 25 & 2752 & 尖 & 23 & 2806 & 奠 & 20 & 2861 & 挀 & 18 & 2907 & 互 & 16 & 2966 & 膀 & 14 \\
\hline 2702 & 黛 & 25 & 2752 & 鉦 & 23 & 2806 & 貝 & 20 & 2861 & 㶲 & 18 & 2907 & 諒 & 16 & 2966 & 胱 & 14 \\
\hline 2702 & 煎 & 25 & 2752 & 餐 & 23 & 2806 & 錨 & 20 & 2861 & 成 & 18 & 2907 & 瞥 & 16 & 2966 & 罠 & 14 \\
\hline 2702 & 凄 & 25 & 2752 & 者 & 23 & 2806 & 氾 & 20 & 2861 & 魏 & 18 & 2907 & 焚 & 16 & 2966 & 䇠 & 14 \\
\hline 2702 & 椙 & 25 & 2772 & 瞠 & 22 & 2806 & 衰 & 20 & 2861 & 咤 & 18 & 2907 & 梅 & 16 & 2966 & 疥 & 14 \\
\hline 2702 & 疹 & 25 & 2772 & 疱 & 22 & 2806 & 汝 & 20 & 2861 & 叟 & 18 & 2907 & 构 & 16 & 2966 & 㗬 & 14 \\
\hline 2702 & 蟻 & 25 & 2772 & 烋 & 22 & 2806 & 吊 & 20 & 2861 & 儲 & 18 & 2907 & 匙 & 16 & 2966 & 璋 & 14 \\
\hline 2725 & 䳺 & 24 & 2772 & 崑 & 22 & 2806 & 吒 & 20 & 2861 & 豹 & 18 & 2907 & 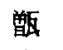 & 16 & 2966 & 㺈 & 14 \\
\hline 2725 & 鱙 & 24 & 2772 & 毀 & 22 & 2806 & 曾 & 20 & 2861 & 倨 & 18 & 2907 & 㗑 & 16 & 2966 & 恸 & 14 \\
\hline 2725 & 藝 & 24 & 2772 & 凌 & 22 & 2806 & 减 & 20 & 2861 & 稗 & 18 & 2907 & 謁 & 16 & 2966 & 軨 & 14 \\
\hline 2725 & 笏 & 24 & 2772 & 赫 & 22 & 2806 & 斯 & 20 & 2861 & 緋 & 18 & 2907 & 洩 & 16 & 2966 & 哭 & 14 \\
\hline 2725 & 琲 & 24 & 2772 & 頒 & 22 & 2806 & 坤 & 20 & 2861 & 碇 & 18 & 2907 & 㙄 & 16 & 2966 & 覟 & 14 \\
\hline 2725 & 现 & 24 & 2772 & 鎧 & 22 & 2806 & 矿 & 20 & 2861 & 蛋 & 18 & 2907 & 稳 & 16 & 2966 & 于 & 14 \\
\hline 2725 & 酒 & 24 & 2772 & 臆 & 22 & 2806 & 鈎 & 20 & 2861 & 苔 & 18 & 2931 & 箖 & 15 & 2966 & 勿 & 14 \\
\hline 2725 & 椒 & 24 & 2772 & 溢 & 22 & 2806 & 妓 & 20 & 2861 & 棈 & 18 & 2931 & 椇 & 15 & 2966 & 亦 & 14 \\
\hline 2725 & 扁 & 24 & 2772 & 亥 & 22 & 2806 & 芫 & 20 & 2861 & 遡 & 18 & 2931 & 閔 & 15 & 2966 & 滕 & 14 \\
\hline 2725 & 重 & 24 & 2772 & 椅 & 22 & 2806 & 㐾 & 20 & 2861 & 詮 & 18 & 2931 & 鉉 & 15 & 2966 & 誹 & 14 \\
\hline 2725 & 哺 & 24 & 2785 & 植 & 21 & 2806 & 迂 & 20 & 2861 & 裳 & 18 & 2931 & 通 & 15 & 2966 & 科 & 14 \\
\hline 2725 & 临 & 24 & 2785 & 闊 & 21 & 2836 & 遥 & 19 & 2886 & 藏 & 17 & 2931 & 萍 & 15 & 2966 & 岱 & 14 \\
\hline 2725 & 椀 & 24 & 2785 & 鏑 & 21 & 2836 & 辣 & 19 & 2886 & 耿 & 17 & 2931 & 舫 & 15 & 2966 & 笥 & 14 \\
\hline 2725 & 蛹 & 24 & 2785 & 臀 & 21 & 2836 & 萠 & 19 & 2886 & 糀 & 17 & 2931 & 聚 & 15 & 2966 & 蝕 & 14 \\
\hline 2725 & 橉 & 24 & 2785 & 筍 & 21 & 2836 & 若 & 19 & 2886 & 管 & 17 & 2931 & 紟 & 15 & 2966 & 㷐 & 14 \\
\hline 2725 & 緬 & 24 & 2785 & 瞰 & 21 & 2836 & 策 & 19 & 2886 & 瘤 & 17 & 2931 & 籔 & 15 & 2966 & 育 & 14 \\
\hline 2725 & 䘠 & 24 & 2785 & 濡 & 21 & 2836 & 礆 & 19 & 2886 & 潜 & 17 & 2931 & 價 & 15 & 2966 & 倦 & 14 \\
\hline 2725 & 轜 & 24 & 2785 & 暎 & 21 & 2836 & 涬 & 19 & 2886 & 潘 & 17 & 2931 & 榕 & 15 & 2966 & 頚 & 14 \\
\hline 2725 & 醒 & 24 & 2785 & 源 & 21 & 2836 & 臬 & 19 & 2886 & 杬 & 17 & 2931 & 恂 & 15 & 2966 & 枯 & 14 \\
\hline 2725 & 梹 & 24 & 2785 & 凛 & 21 & 2836 & 哠 & 19 & 2886 & 晨 & 17 & 2931 & 彷 & 15 & 2966 & 碍 & 14 \\
\hline 2725 & 咋 & 24 & 2785 & 䙵 & 21 & 2836 & 噪 & 19 & 2886 & 嘔 & 17 & 2931 & 裹 & 15 & 2966 & 被 & 14 \\
\hline 2725 & 厤 & 24 & 2785 & 蓬 & 21 & 2836 & 喻 & 19 & 2886 & 伶 & 17 & 2931 & 쓰 & 15 & 2996 & 璘 & 13 \\
\hline 2725 & 乞 & 24 & 2785 & 埠 & 21 & 2836 & 妏 & 19 & 2886 & 沃 & 17 & 2931 & 侽 & 15 & 2996 & 韶 & 13 \\
\hline 2725 & 汲 & 24 & 2785 & 甽 & 21 & 2836 & 霜 & 19 & 2886 & 贸 & 17 & 2931 & 傀 & 15 & 2996 & 踓 & 13 \\
\hline 2725 & 勃 & 24 & 2785 & 腿 & 21 & 2836 & 籵 & 19 & 2886 & 馳 & 17 & 2931 & 娻 & 15 & 2996 & 鏡 & 13 \\
\hline 2725 & 黨 & 24 & 2785 & 揃 & 21 & 2836 & 斧 & 19 & 2886 & 單 & 17 & 2931 & 燐 & 15 & 2996 & 賤 & 13 \\
\hline $\mathrm{CF}$ & & $\longdiv { 5 3 1 }$ & 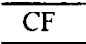 & & 9581 & $\begin{array}{l}\mathrm{CF} \\
\end{array}$ & & 9631 & $\begin{array}{l}\mathrm{CF} \\
\end{array}$ & & .9681 & $\mathrm{CF}$ & & 9.9731 & $\mathrm{CF}$ & & 9781 \\
\hline
\end{tabular}


APPENDIX A (Continued)

\begin{tabular}{|c|c|c|}
\hline $\bar{R}$ & $\mathrm{C}$ & $\bar{F}$ \\
\hline 2996 & 䙎 & 13 \\
\hline 2996 & 艀 & 13 \\
\hline 2996 & 濾 & 13 \\
\hline 2996 & 腑 & 13 \\
\hline 2996 & 聶 & 13 \\
\hline 2996 & 聘 & 13 \\
\hline 2996 & 桱 & 13 \\
\hline 2996 & 籃 & 13 \\
\hline 2996 & 昫 & 13 \\
\hline 2996 & 榴 & 13 \\
\hline 2996 & 楷 & 13 \\
\hline 2996 & 梵 & 13 \\
\hline 2996 & 特 & 13 \\
\hline 2996 & 學 & 13 \\
\hline 2996 & 娜 & 13 \\
\hline 2996 & 俯 & 13 \\
\hline 2996 & 噊 & 13 \\
\hline 2996 & 恣 & 13 \\
\hline 2996 & 㽚 & 13 \\
\hline 2996 & 扮 & 13 \\
\hline 2996 & 楳 & 13 \\
\hline 2996 & 遁 & 13 \\
\hline 2996 & 䯚 & 13 \\
\hline 2996 & 香 & 13 \\
\hline 2996 & 浣 & 13 \\
\hline 2996 & 嬏 & 13 \\
\hline 2996 & 鞘 & 13 \\
\hline 2996 & 鮭 & 13 \\
\hline 2996 & 坸 & 13 \\
\hline 2996 & 劫 & 13 \\
\hline 2996 & 怯 & 13 \\
\hline 2996 & 鋸 & 13 \\
\hline 2996 & 笋 & 13 \\
\hline 2996 & 盈 & 13 \\
\hline$\overline{C F}$ & & 9815 \\
\hline
\end{tabular}

Note- $\mathrm{R}=$ Rank of frequency, $\mathrm{C}=$ Character of kanji, $\mathrm{F}=$ Frequency occurrence in $23,408,236$ character corpus.
APPENDIX B

Hiragana Letter Frequency List

\begin{tabular}{|c|c|c|c|c|c|}
\hline$R$ & $\mathrm{C}$ & $\mathrm{F}$ & $\mathbf{R}$ & $\mathrm{C}$ & $F$ \\
\hline 1 & & 1918313 & 49 & ほ & 48752 \\
\hline 2 & に & 1108840 & 50 & $\sim$ & 47013 \\
\hline 3 & $\hbar$ & 1067566 & 51 & び & 32312 \\
\hline 4 & W & 1060284 & 52 & t & 31212 \\
\hline 5 & 杜 & 937811 & 53 & $\Xi$ & 26965 \\
\hline 6 & 莸 & 936356 & 54 & 放 & 23490 \\
\hline 7 & と & 927938 & 55 & \$゙ & 23280 \\
\hline 8 & る & 916652 & 56 & ぐ & 21549 \\
\hline 9 & が & 860742 & 57 & ぎ & 19865 \\
\hline 10 & L & 848132 & 58 & $u$ & 19148 \\
\hline 11 & で & 764834 & 59 & 上 & 14425 \\
\hline 12 & $\tau$ & 758316 & 60 & ガ & 13125 \\
\hline 13 & な & 720156 & 61 & ぼ & 12402 \\
\hline 14 & 加 & 537294 & 62 & ざ & 12108 \\
\hline 15 & 2 & 467350 & 63 & S & 11606 \\
\hline 16 & $れ$ & 450805 & 64 & や & 11522 \\
\hline 17 & 5 & 423294 & 65 & ぞ & 10047 \\
\hline 18 & 8 & 396142 & 66 & ゆ & 8486 \\
\hline 19 & 5 & 352965 & 67 & ぜ & 6893 \\
\hline 20 & す & 340654 & 68 & $ぬ 2$ & 5124 \\
\hline 21 & $\eta$ & 333999 & 69 & ぱ & 4349 \\
\hline 22 & $こ$ & 312227 & 70 & $\Phi$ & 2755 \\
\hline 23 & だ & 280911 & 71 & $ひ ゚$ & 1608 \\
\hline 24 & ま & 278599 & 72 & ぽ & 1315 \\
\hline 25 & $さ$ & 258960 & 73 & $S^{\circ}$ & 986 \\
\hline 26 & き & 233505 & 74 & ペ & 477 \\
\hline 27 & め & 223806 & 75 & あ & 125 \\
\hline 28 & $<$ & 221960 & 76 & え & 106 \\
\hline 29 & あ & 204256 & 77 & ぢ & 82 \\
\hline 30 & け & 199362 & 78 & 勇 & 75 \\
\hline 31 & ビ & 196555 & 79 & み & 48 \\
\hline 32 & $h$ & 190068 & 80 & お & 21 \\
\hline 33 & え & 163664 & 81 & $w$ & 21 \\
\hline 34 & $よ$ & 154206 & 82 & $わ$ & 3 \\
\hline 35 & 2 & 153999 & 83 & 5 & 1 \\
\hline
\end{tabular}

36 や 146156

37 そ 131611

38 わ 123077

39 ち 99183

40 み 89264

41 せ 83444

42 万 73467

43 ば 72228

44 打 65870

45 じ 56857

46 ベ 56005

47 ず 53256

48 げ 49126

Note $-\mathrm{R}=$ Rank of frequency, $\mathrm{C}=$ Character of hiragana, $\mathrm{F}=$ Frequency occurrence in $20,711,361$ character corpus. 
APPENDIX C

Katakana Letter Frequency List

\begin{tabular}{|c|c|c|c|c|c|}
\hline $\mathrm{R}$ & $\mathrm{C}$ & $F$ & $\mathbf{R}$ & $\mathrm{C}$ & $\mathrm{F}$ \\
\hline 1 & ン & 290948 & 49 & 交 & 22462 \\
\hline 2 & ル & 189442 & 50 & ガ & 22061 \\
\hline 3 & ㅈ & 178214 & 51 & 八 & 21839 \\
\hline 4 & ト & 162802 & 52 & ワ & 21784 \\
\hline 5 & $\boldsymbol{r}$ & 127845 & 53 & y & 20784 \\
\hline 6 & 1 & 120807 & 54 & ケ & 20633 \\
\hline 7 & ラ & 117203 & 55 & モ & 20070 \\
\hline 8 & リ & 106744 & 56 & 1 & 19572 \\
\hline 9 & ク & 98209 & 57 & ズ & 19240 \\
\hline 10 & \% & 86894 & 58 & ピ & 18692 \\
\hline 11 & 力 & 82982 & 59 & ホ & 18204 \\
\hline 12 & シ & 80626 & 60 & $I$ & 17817 \\
\hline 13 & タ & 75319 & 61 & $\exists$ & 17731 \\
\hline 14 & 미 & 75301 & 62 & ペ & 14881 \\
\hline 15 & ド & 74257 & 63 & $\exists ゙$ & 13931 \\
\hline 16 & ジ & 61171 & 64 & $ヤ$ & 12526 \\
\hline 17 & 7 & 61115 & 65 & ギ & 10732 \\
\hline 18 & L & 60608 & 66 & $\exists$ & 10318 \\
\hline 19 & $x$ & 60230 & 67 & ザ & 10144 \\
\hline 20 & ב & 58724 & 68 & $\boldsymbol{\gamma}$ & 10121 \\
\hline 21 & $\nabla$ & 56123 & 69 & ゼ & 7689 \\
\hline 22 & プ & 54159 & 70 & ヒ & 7289 \\
\hline 23 & $\bar{\tau}$ & 53404 & 71 & ヘ & 7129 \\
\hline 24 & 厶 & 50758 & 72 & 그 & 6653 \\
\hline 25 & f & 48437 & 73 & $ケ ゙$ & 6481 \\
\hline 26 & バ & 44970 & 74 & オ & 6245 \\
\hline 27 & ビ & 44462 & 75 & ヌ & 2897 \\
\hline 28 & グ & 40433 & 76 & ゾ & 2640 \\
\hline 29 & $\neq$ & 39608 & 77 & ヴ & 1145 \\
\hline 30 & ウ & 39323 & 78 & ウ & 1050 \\
\hline 31 & サ & 39202 & 79 & $\mathscr{F}$ & 149 \\
\hline 32 & $=$ & 38711 & 80 & ツ & 127 \\
\hline 33 & ナ & 38047 & 81 & 7 & 122 \\
\hline 34 & $I$ & 36458 & 82 & I & 73 \\
\hline 35 & ブ & 35920 & 83 & 中 & 40 \\
\hline 36 & パ & 35416 & 84 & 力 & 14 \\
\hline 37 & セ & 34883 & 85 & $\square$ & 9 \\
\hline 38 & オ & 34718 & 86 & r & 2 \\
\hline 39 & 1 & 33747 & & & \\
\hline 40 & $\overrightarrow{7}$ & 32665 & & & \\
\hline 41 & $I$ & 32616 & & & \\
\hline 42 & $\$$ & 29262 & & & \\
\hline 43 & ヤ & 28144 & & & \\
\hline 44 & ボ & 26651 & & & \\
\hline $\begin{array}{l}45 \\
46\end{array}$ & $\begin{array}{l}\not ゙ \\
ッ\end{array}$ & $\begin{array}{l}26396 \\
24541\end{array}$ & & & \\
\hline 47 & ポ & 23742 & & & \\
\hline 48 & ベ & 22755 & & & \\
\hline
\end{tabular}

Note- $\mathrm{R}=$ Rank of frequency, $\mathrm{C}=$ Character of katakana, $\mathrm{F}=$ Frequency occurrence in $3,608,288$ character corpus.

(Manuscript received February 2, 1999;

revision accepted for publication February 27, 2000.) 